\title{
Boron Hydrogen Compounds: Hydrogen Storage and Battery Applications
}

\author{
Hans Hagemann
}

check for updates

Citation: Hagemann, H. Boron Hydrogen Compounds: Hydrogen Storage and Battery Applications. Molecules 2021, 26, 7425. https:// doi.org/10.3390/molecules26247425

Academic Editors: Andrea Rossin, Igor Golub and Vladimir Bregadze

Received: 15 October 2021

Accepted: 2 December 2021

Published: 7 December 2021

Publisher's Note: MDPI stays neutral with regard to jurisdictional claims in published maps and institutional affiliations.

Copyright: (c) 2021 by the author Licensee MDPI, Basel, Switzerland. This article is an open access article distributed under the terms and conditions of the Creative Commons Attribution (CC BY) license (https:// creativecommons.org/licenses/by/ $4.0 /)$.
Département de Chimie Physique, Université de Genève, 30, Quai E. Ansermet, CH1211 Geneva 4, Switzerland; hans-rudolf.hagemann@unige.ch

\begin{abstract}
About 25 years ago, Bogdanovic and Schwickardi (B. Bogdanovic, M. Schwickardi: J. Alloys Compd. 1-9, 253 (1997) discovered the catalyzed release of hydrogen from $\mathrm{NaAlH}_{4}$. This discovery stimulated a vast research effort on light hydrides as hydrogen storage materials, in particular boron hydrogen compounds. $\mathrm{Mg}\left(\mathrm{BH}_{4}\right)_{2}$, with a hydrogen content of $14.9 \mathrm{wt} \%$, has been extensively studied, and recent results shed new light on intermediate species formed during dehydrogenation. The chemistry of $\mathrm{B}_{3} \mathrm{H}_{8}{ }^{-}$, which is an important intermediate between $\mathrm{BH}_{4}{ }^{-}$and $\mathrm{B}_{12} \mathrm{H}_{12}{ }^{2-}$, is presented in detail. The discovery of high ionic conductivity in the high-temperature phases of $\mathrm{LiBH}_{4}$ and $\mathrm{Na}_{2} \mathrm{~B}_{12} \mathrm{H}_{12}$ opened a new research direction. The high chemical and electrochemical stability of closo-hydroborates has stimulated new research for their applications in batteries. Very recently, an all-solid-state $4 \mathrm{~V}$ Na battery prototype using a $\mathrm{Na}_{4}\left(\mathrm{CB}_{11} \mathrm{H}_{12}\right)_{2}\left(\mathrm{~B}_{12} \mathrm{H}_{12}\right)$ solid electrolyte has been demonstrated. In this review, we present the current knowledge of possible reaction pathways involved in the successive hydrogen release reactions from $\mathrm{BH}_{4}{ }^{-}$to $\mathrm{B}_{12} \mathrm{H}_{12}{ }^{2-}$, and a discussion of relevant necessary properties for high-ionic-conduction materials.
\end{abstract}

Keywords: boron hydrides; hydrogen storage; solid ionic conductors

\section{Introduction}

Boron hydrogen compounds have been intensively studied for almost a century since the pioneering studies of A. Stock [1]. Boron hydrogen compounds are also energetic materials and were considered as rocket or jet fuels [2]; however, the toxicity of boranes has prevented their extended use. Currently, nontoxic compounds such as ammonia-borane are also studied as hypergolic propellants [3,4]. Recently, many different applications of boron hydrogen compounds have emerged [5]. In particular, compounds derived from closo-hydroborates such as $\mathrm{B}_{12} \mathrm{H}_{12}{ }^{2-}$ have found many new applications, including new all-solid-state batteries, medical applications, and as catalysts [6-11]. Since the discovery of catalyzed hydrogen release in $\mathrm{NaAlH}_{4}$ by Bogdanovic and Schwickardi [12], light boron and aluminum hydrides were intensively studied and reviewed as potential hydrogen storage materials [13-22]. The dehydrogenation reactions of metal borohydrides ultimately lead to hydrogen, metal and boron, or metal borides. In this reaction process, intermediate species are formed, particularly compounds with closo-hydroborate anion $\mathrm{B}_{12} \mathrm{H}_{12}{ }^{2-}[23,24]$. $\mathrm{B}_{12} \mathrm{H}_{12}{ }^{2-}$ is particularly stable and can thus also act as a detrimental thermodynamic sink for further dehydrogenation reactions. The properties of closo-hydroborates and related anions were addressed in several recent publications [6,25-28]. New research on the thermal properties of closo-hydroborate salts revealed a high-temperature phase transition in $\mathrm{Na}_{2} \mathrm{~B}_{12} \mathrm{H}_{12}$ leading to a superionic phase [29]. Thus, the controlled dehydrogenation of a borohydride salt can be used to safely prepare new closo- and nido-hydroborate salts for potential battery applications [30] without using toxic boranes such as $\mathrm{B}_{10} \mathrm{H}_{14}$, which were used for the synthesis of this large boron species [31].

In this review, we first describe experimental results on hydrogen storage in $\mathrm{Mg}\left(\mathrm{BH}_{4}\right)_{2}$, which has a large hydrogen content of $14.9 \mathrm{wt} \%$. Hydrogen storage in other borohydrides, such as $\mathrm{LiBH}_{4}$, was recently reviewed [32]. Recent results on potential dehydrogenation 
intermediates for $\mathrm{Mg}\left(\mathrm{BH}_{4}\right)_{2}$ provide new insights on the potential reaction intermediates and are reported here. In this context, we then present recent results based on DFT calculations to explore possible reaction paths for successive dehydrogenation reactions starting from $\mathrm{BH}_{4}{ }^{-}$. These paths are described in more detail in the following section, which discusses the formation and reactions of $\mathrm{B}_{3} \mathrm{H}_{8}{ }^{-}$, as this ion is considered to be one of the reaction intermediates during the dehydrogenation of borohydride compounds. The high-temperature dehydrogenation of $\mathrm{B}_{3} \mathrm{H}_{8}{ }^{-}$leads to the formation of closo-hydroborate anions $\mathrm{B}_{10} \mathrm{H}_{10}{ }^{2-}$ and $\mathrm{B}_{12} \mathrm{H}_{12}{ }^{2-}$, which form excellent solid ionic conductors for new allsolid-state batteries [30]. The properties of these ionic conductors are presented in the last section.

\section{Magnesium Borohydride}

Among the many compounds considered for hydrogen storage, $\mathrm{Mg}\left(\mathrm{BH}_{4}\right)_{2}$ is particularly interesting and has been studied by many authors. The earlier studies on $\mathrm{Mg}\left(\mathrm{BH}_{4}\right)_{2}$ were reviewed in detail in 2016 [22]. $\mathrm{Mg}\left(\mathrm{BH}_{4}\right)_{2}$ has a hydrogen content of 14.9 mass \% [22,33]. This compound can be prepared in different crystalline modifications, and high pressurephase transitions were also observed [33]. Porous $\gamma-\mathrm{Mg}\left(\mathrm{BH}_{4}\right)_{2}$ can also adsorb $0.8 \mathrm{H}_{2}$ at low temperatures and 100 bar to achieve a total hydrogen mass content of $17.4 \%$ [33]. High-pressure phase $\delta-\mathrm{Mg}\left(\mathrm{BH}_{4}\right)_{2}$ has a very high volumetric hydrogen content of $147 \mathrm{~g} \mathrm{H}_{2} / \mathrm{L}$. $\mathrm{Mg}\left(\mathrm{BH}_{4}\right)_{2}$ can also form amorphous solids. Overall dehydrogenation reaction

$$
\mathrm{Mg}\left(\mathrm{BH}_{4}\right)_{2} \rightarrow \mathrm{MgB}_{2}+4 \mathrm{H}_{2}
$$

is, in fact, a multistep reaction (see Figure 1) with various reaction intermediates, such as $\mathrm{Mg}\left(\mathrm{B}_{3} \mathrm{H}_{8}\right)_{2}, \mathrm{MgH}_{2}$, and $\mathrm{MgB}_{12} \mathrm{H}_{12}$, which were proposed both experimentally and theoretically [22,34-36]. $\mathrm{MgB}_{2}$ is the decomposition product obtained after heating to $500{ }^{\circ} \mathrm{C}$ [37]. Boron-rich $\mathrm{MgB}_{7}$ films are obtained by heating volatile $\mathrm{Mg}\left(\mathrm{B}_{3} \mathrm{H}_{8}\right)_{2}$ solvates with dimethyl ether and diethyl ether [38].

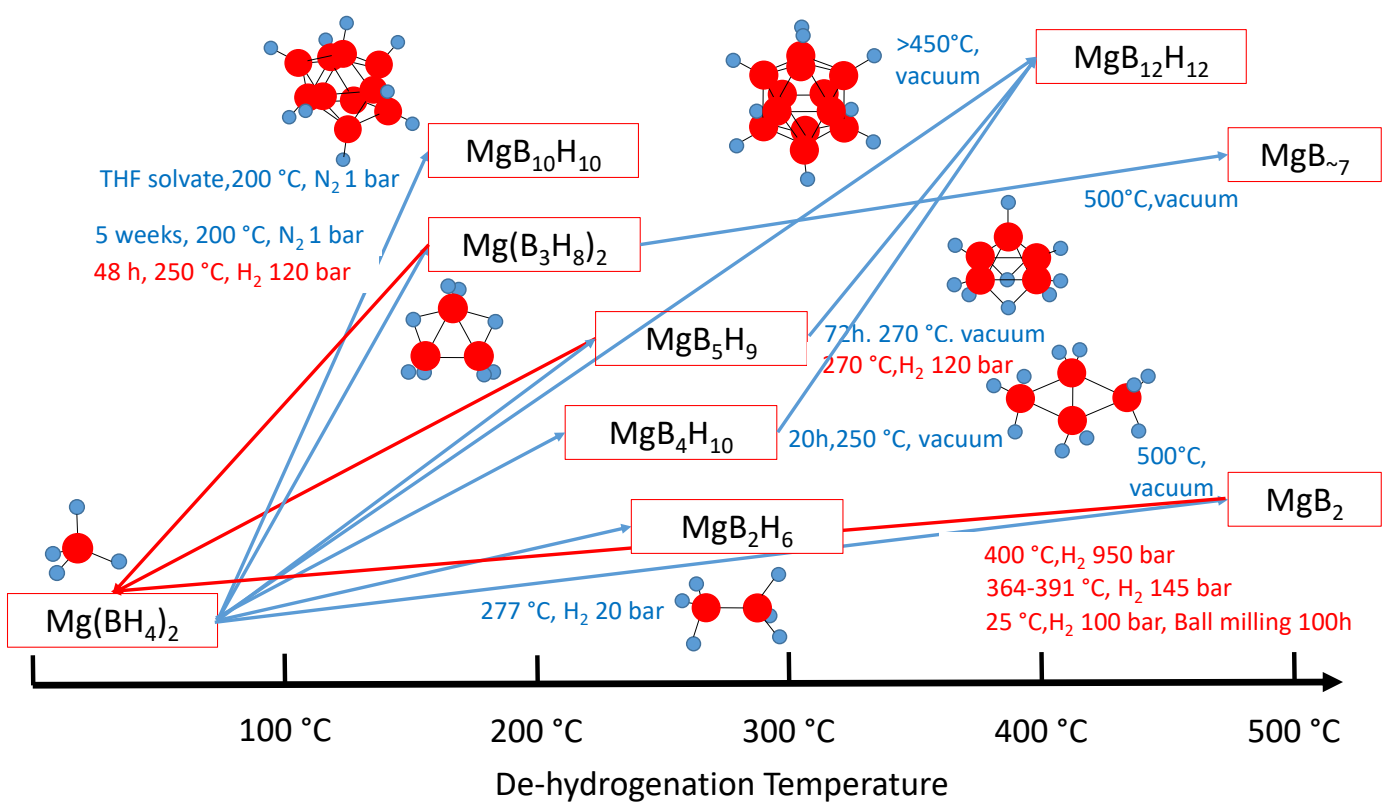

Figure 1. Illustration of $\mathrm{Mg}\left(\mathrm{BH}_{4}\right)_{2}$ dehydrogenation reactions (blue arrows) and rehydrogenation reactions (red arrows) reported in the literature [22,34-44]. Upon further heating, these intermediate species, which are associated with (amorphous) $\mathrm{MgH}_{2}$, form $\mathrm{MgB}_{2}$.

$\mathrm{MgB}_{2}$ can be rehydrogenated, although under drastic conditions (950 bar $\mathrm{H}_{2}$ at $400{ }^{\circ} \mathrm{C}$ ) [40]. The rehydrogenation of $\mathrm{MgB}_{2}$ can be accelerated with $\mathrm{THF}, \mathrm{MgH}_{2}$, and $\mathrm{Mg}$ [41]. Mechanically milled mixtures of $\mathrm{MgB}_{2}, \mathrm{THF}$, and $40 \mathrm{~mol} \% \mathrm{Mg}$ could thus ab- 
sorb $6 \mathrm{wt} \%$ of $\mathrm{H}_{2}$ at $300{ }^{\circ} \mathrm{C}$ under 700 bar of $\mathrm{H}_{2}$, which is less drastic than that without THF. Recently, rehydrogenation at room temperature with mechanical activation by ball milling was reported [42]. These rehydrogenation reactions of $\mathrm{MgB}_{2}$ demonstrate the principle that hydrogen storage in $\mathrm{Mg}\left(\mathrm{BH}_{4}\right)_{2}$ is indeed reversible. A recent combined experimental and theoretical study concluded that the initial stages of rehydrogenation are associated with the formation of $\sigma$ bonds of hydrogen with boron on the reactive edges of the $\mathrm{MgB}_{2}$ solid [43]. The rehydrogenation of intermediate compounds was also studied. $\mathrm{MgB}_{3} \mathrm{H}_{8}$. THF can be rehydrogenated under milder conditions than those of dry $\mathrm{MgB}_{3} \mathrm{H}_{8}$

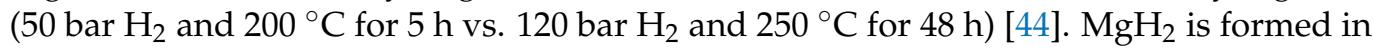
intermediate reaction steps, such as

$$
6 \mathrm{Mg}\left(\mathrm{BH}_{4}\right)_{2} \rightarrow \mathrm{MgB}_{12} \mathrm{H}_{12}+5 \mathrm{MgH}_{2}+13 \mathrm{H}_{2}
$$

Magnesium hydride dissociates into $\mathrm{Mg}$ and $\mathrm{H}_{2}$ at high temperatures and low $\mathrm{H}_{2}$ pressures. The different reaction products observed under various conditions (see Figure 1) show that the reaction kinetics can be influenced by various parameters, which also include the initial crystalline modification of $\mathrm{Mg}\left(\mathrm{BH}_{4}\right)_{2}$.

The overall enthalpy of reaction for the dehydrogenation of $\mathrm{Mg}\left(\mathrm{BH}_{4}\right)_{2}\left(\Delta_{\mathrm{f}} \mathrm{H}^{\circ}=\right.$ $-208 \mathrm{~kJ} / \mathrm{mol})$ to form $\mathrm{MgB}_{2}\left(\Delta_{\mathrm{f}} \mathrm{H}^{\circ}=-91.96 \mathrm{~kJ} / \mathrm{mol}\right)$ and hydrogen can be calculated [45-47] to be equal to $+116 \mathrm{~kJ} / \mathrm{mol}$, i.e., less than $30 \mathrm{~kJ} / \mathrm{mol}$ per hydrogen molecule released, which is, in principle, in the correct range for a hydrogen storage material [13]. The first step of a dehydrogenation reaction of $\mathrm{BH}_{4}{ }^{-}$is likely to be the breaking of a $\mathrm{B}-\mathrm{H}$ bond. Isotope exchange reactions of $\mathrm{Mg}\left(\mathrm{BH}_{4}\right)_{2}$ with $\mathrm{D}_{2}$ allow for producing a complete exchange to form $\mathrm{Mg}\left(\mathrm{BD}_{4}\right)_{2}$, and the corresponding activation energy was estimated to be about $51 \mathrm{~kJ} / \mathrm{mol}$ [48]. For $\mathrm{Ca}\left(\mathrm{BH}_{4}\right)_{2}$, the corresponding activation energy was found to be 82 and $98.5 \mathrm{~kJ} / \mathrm{mol}$ for the reverse reaction, confirming that breaking a bond with hydrogen or deuterium is the rate-limiting step [49]. Theoretical calculations of potential defects in $\mathrm{Mg}\left(\mathrm{BH}_{4}\right)_{2}$ suggest that, in the initial phase of the dehydrogenation, $\mathrm{a} \mathrm{H}^{-}$ion is formed that can diffuse in the lattice [50]. On the other hand, gas diffusion in the solid is also a contribution to exchange kinetics, as was shown by isotope exchange reactions with the highly porous modification of $\gamma-\mathrm{Mg}\left(\mathrm{BH}_{4}\right)_{2}$ with a high surface area compared to a ball-milled sample with a strongly reduced surface aera [51].

The reaction kinetics of hydrogen release in $\mathrm{Mg}\left(\mathrm{BH}_{4}\right)_{2}$ can be significantly enhanced by various additives, such as $\mathrm{TiCl}_{3}$ [52] or $\mathrm{NbF}_{5}$ and $\mathrm{TiO}_{2}$ [53]. Lewis bases in the form of solvates of $\mathrm{Mg}\left(\mathrm{BH}_{4}\right)_{2}$ can also accelerate the hydrogen release [54]. As shown in Figure 1, the THF solvate releases $\mathrm{H}_{2}$ gas below $200{ }^{\circ} \mathrm{C}$ to form $\mathrm{Mg}\left(\mathrm{B}_{10} \mathrm{H}_{10}\right)$. The formation of $\mathrm{B}_{3} \mathrm{H}_{8}{ }^{-}$ and $\mathrm{B}_{12} \mathrm{H}_{12}{ }^{2-}$ was also observed, but with THF and dimethyl ether, $\mathrm{B}_{12} \mathrm{H}_{12}{ }^{2-}$ remained a minor reaction product. The physical properties of $\mathrm{Mg}\left(\mathrm{BH}_{4}\right)_{2}$.3THF were recently investigated in detail [55]. In this compound, $\mathrm{Mg}^{2+}$ is coordinated to $2 \mathrm{BH}_{4}^{-}$ions and $3 \mathrm{THF}$ molecules. The orientational mobilities of the $\mathrm{BH}_{4}{ }^{-}$ions are not particularly sensitive to the presence of THF. The authors concluded that "the presence of THF also disrupts the stability of the crystalline phase leading to enhanced kinetics for the dehydrogenations". Recently, Tran et al. [56] reported that the presence of different glymes with $\mathrm{Mg}\left(\mathrm{BH}_{4}\right)_{2}$ results in various ratios of $\mathrm{MgB}_{10} \mathrm{H}_{10}$ and $\mathrm{MgB}_{12} \mathrm{H}_{12}$ upon thermolysis at $160-200{ }^{\circ} \mathrm{C}$, and allows for selectively obtaining $\mathrm{MgB}_{10} \mathrm{H}_{10}$ with one equivalent of monoglyme. Mixtures of $\mathrm{Mg}\left(\mathrm{BH}_{4}\right)_{2}$ with $\left(\mathrm{CH}_{3}\right)_{4} \mathrm{NBH}_{4}$ (5:1 molar) reveal reversible melting around 180-195 ${ }^{\circ} \mathrm{C}$ [57] with enhanced stability compared to melts of pure $\mathrm{Mg}\left(\mathrm{BH}_{4}\right)_{2}$ and $\left(\mathrm{CH}_{3}\right)_{4} \mathrm{NBH}_{4}$. $\left[\mathrm{Ph}_{4} \mathrm{P}_{2}\left[\mathrm{Mg}\left(\mathrm{BH}_{4}\right)_{4}\right]\right.$ gradually loses mass over $225-230{ }^{\circ} \mathrm{C}$, but heating to $500{ }^{\circ} \mathrm{C}$ does not lead to the mass loss expected for the formation of $\mathrm{MgB}_{2}$. A similar behavior was observed for $\left[\mathrm{Me}_{4} \mathrm{~N}_{2}\left[\mathrm{Mg}\left(\mathrm{BH}_{4}\right)_{4}\right]\right.$ [58]. These findings suggest that derivates of $\mathrm{Mg}\left(\mathrm{BH}_{4}\right)_{2}$ with organic cations are rather stabilized.

Solvent-free $\mathrm{Mg}\left(\mathrm{B}_{3} \mathrm{H}_{8}\right)_{2}$ can be prepared by ball milling $\mathrm{MgBr}_{2}$ with $\mathrm{NaB}_{3} \mathrm{H}_{8}[38,59]$. Kim et al. [38] reported the formation of boron-rich $\mathrm{MgB}_{7}$ films upon heating under vacuum above $425{ }^{\circ} \mathrm{C}$ due to some evaporation of $\mathrm{Mg}$ under these conditions. Thermogravimetry (TG) experiments [59] revealed a $30 \mathrm{wt} \%$ mass loss setting in above ca $80{ }^{\circ} \mathrm{C}$ corresponding to the evolution of $\mathrm{B}_{2} \mathrm{H}_{6}, \mathrm{~B}_{5} \mathrm{H}_{9}$ and $\mathrm{H}_{2}$. The residual solid after heating to $20{ }^{\circ} \mathrm{C}$ was a 
mixture of mainly $\mathrm{Mg}\left(\mathrm{BH}_{4}\right)_{2}, \mathrm{Mg}\left(\mathrm{B}_{10} \mathrm{H}_{10}\right)$, and $\mathrm{Mg}\left(\mathrm{B}_{12} \mathrm{H}_{12}\right)$, and the combined evolution of $\mathrm{H}_{2}, \mathrm{~B}_{2} \mathrm{H}_{6}$, and $\mathrm{B}_{5} \mathrm{H}_{9}$ was confirmed by mass spectrometry [60]. The addition of activated (ball-milled) $\mathrm{MgH}_{2}$ to $\mathrm{Mg}\left(\mathrm{B}_{3} \mathrm{H}_{8}\right)_{2}$ results in a strong reduction in borane evolution and up to $88 \%$ conversion back to $\mathrm{Mg}\left(\mathrm{BH}_{4}\right)_{2}$ at $100{ }^{\circ} \mathrm{C}$. The presence of activated $\mathrm{MgH}_{2}$ thus substantially decreases the formation of (closo-hydro)borates and provides the necessary hydrogen for the conversion of $\mathrm{B}_{3} \mathrm{H}_{8}{ }^{-}$back into $\mathrm{BH}_{4}{ }^{-}$.

These experiments suggest that, while Lewis acids may favor the dehydrogenation reactions of $\mathrm{Mg}\left(\mathrm{BH}_{4}\right)_{2}$, they do not necessarily catalyze the rehydrogenation reactions, as transition metal halides do not appear to affect the rehydrogenation of $\mathrm{MgB}_{2}[40,61]$. THF and other Lewis bases appear to accelerate both the dehydrogenation and rehydrogenation reactions of $\mathrm{Mg}\left(\mathrm{BH}_{4}\right)_{2}$, and encourage more studies to even further improve the kinetics.

\section{DFT Calculations}

The results presented above for $\mathrm{Mg}\left(\mathrm{BH}_{4}\right)_{2}$ suggest the formation of various intermediate species such as $\mathrm{B}_{2} \mathrm{H}_{6}{ }^{2-}, \mathrm{B}_{3} \mathrm{H}_{8}{ }^{-}, \mathrm{B}_{4} \mathrm{H}_{10}{ }^{2-}$, $\mathrm{B}_{5} \mathrm{H}_{9}{ }^{2-}$ and the closo-borates $\mathrm{B}_{\mathrm{n}} \mathrm{H}_{\mathrm{n}}{ }^{2-}$ $(n=8-12)$. For hydrogen storage applications, the only gaseous species resulting from dehydrogenation reactions should be hydrogen; thus, neutral boranes are a priori not involved in the reaction mechanisms. Many other anionic boron hydrides have been reported in the literature and could be involved in one reaction step or another. In 1999, some reactions between neutral and anionic boron hydrides related to the formation of $\mathrm{B}_{3} \mathrm{H}_{8}{ }^{-}, \mathrm{B}_{5}$ anions, and some other species were reviewed [62].

In order to assess the driving forces for different reactions, thermodynamic information can be very useful, but experimental data are very scarce. For alkali borohydrides, thermodynamical data are available [47], but only few other experimental data are available. Using the experimental values of the formation enthalpy of $\mathrm{Mg}\left(\mathrm{BH}_{4}\right)_{2}$ [45] and $\mathrm{La}\left(\mathrm{BH}_{4}\right)_{3}$ [63], the formation enthalpy of other $\mathrm{M}\left(\mathrm{BH}_{4}\right)_{2}$ and $\mathrm{M}\left(\mathrm{BH}_{4}\right)_{3}$ compounds were estimated, assuming that the lattice enthalpy of bromides and borohydrides with the same metal ion were identical within about $15 \mathrm{~kJ} / \mathrm{mol}$ [46]. The experimental formation enthalpy of $\mathrm{NH}_{4} \mathrm{~B}_{3} \mathrm{H}_{8}(-530 \pm 33 \mathrm{~kJ} / \mathrm{mol})$ [64], $\left(\mathrm{NH}_{4}\right)_{2} \mathrm{~B}_{10} \mathrm{H}_{10}(-359.2 \pm 10 \mathrm{~kJ} / \mathrm{mol})$ [65], and of guanidinium and other nitrogen-based closo-borates was reported [66]. Recently, new heat capacity measurements for $\mathrm{Na}, \mathrm{K}, \mathrm{Rb}, \mathrm{Cs}, \mathrm{Mg}$, Ca borohydrides were reported [67]. The knowledge of all thermodynamic properties in principle allows for quantitatively describing the phase diagram of a system, which was performed using available data for the $\mathrm{Mg}-\mathrm{B}-\mathrm{H}$ system [68].

In the absence of experimental data, theoretical data are obtained. It is quite challenging to obtain accurate results of formation enthalpies using DFT. Nguyen et al. [69] calculated for the formation enthalpy of $\left(\mathrm{NH}_{4}\right)_{2} \mathrm{~B}_{10} \mathrm{H}_{10}$ with the $\mathrm{G} 3$ method the value of $-184 \mathrm{~kJ} / \mathrm{mol}$, which is quite different from the experimental value of $-359.2 \mathrm{~kJ} / \mathrm{mol}$. For $\alpha-\mathrm{Mg}\left(\mathrm{BH}_{4}\right)_{2}$, formation enthalpy values ranging from -67 to $-277 \mathrm{~kJ} / \mathrm{mol}$ were reported in the literature [68], while the experimental value was $-208 \mathrm{~kJ} / \mathrm{mol}$ [45]. Zhang et al. [23] computed relative formation energies of potential solid intermediates formed during the dehydrogenation of $\mathrm{Mg}\left(\mathrm{BH}_{4}\right)_{2}$, in combination with a Monte Carlo-based structure prediction method. They predicted a potential $\mathrm{Mg}_{3}\left(\mathrm{~B}_{3} \mathrm{H}_{6}\right)_{2}$ intermediate with a $\mathrm{B}_{3} \mathrm{H}_{6}{ }^{3-}$ ion, while $\mathrm{Mg}\left(\mathrm{B}_{3} \mathrm{H}_{8}\right)_{2}$ was found to be very high in relative energy and thereby unlikely to be formed.

The principal difficulty for estimating the formation enthalpy of crystalline solids is the evaluation of lattice energy, as different approaches (volume-based, Kaputinski equation etc.) lead to different values. Further, lattice energies can only be computed for crystalline materials, preferentially on the basis of experimental structure data, but experiments showed that a significant fraction of the reaction intermediates remain amorphous, complicating things even further.

DFT calculations in the gas phase are quite reliable, and allow for obtaining good structural data and vibrational frequencies, in particular when anharmonicity is included. Several studies report the formation enthalpy of borohydride ions in the gas phase [69-72] 
Anharmonic DFT calculations allow for obtaining improved agreement with experimental vibrational spectra, from which heat capacity data were calculated [73]. Figure 2 compares experimental [74] and DFT calculated [69-72] formation enthalpy data for neutral and anionic boron hydrogen species. Figure 2 shows that the calculated formation enthalpy for a given species (e.g., $\mathrm{B}_{3} \mathrm{H}_{8}{ }^{-}$) can differ by about $100 \mathrm{~kJ} /$ mole for different sources. These values are derived, for instance, from isodesmic reactions with known formation heat [69], thus generating a potential propagation of errors if the initial formation enthalpy values are different. We outline all reported values to highlight the limitations of the accuracy of these data.

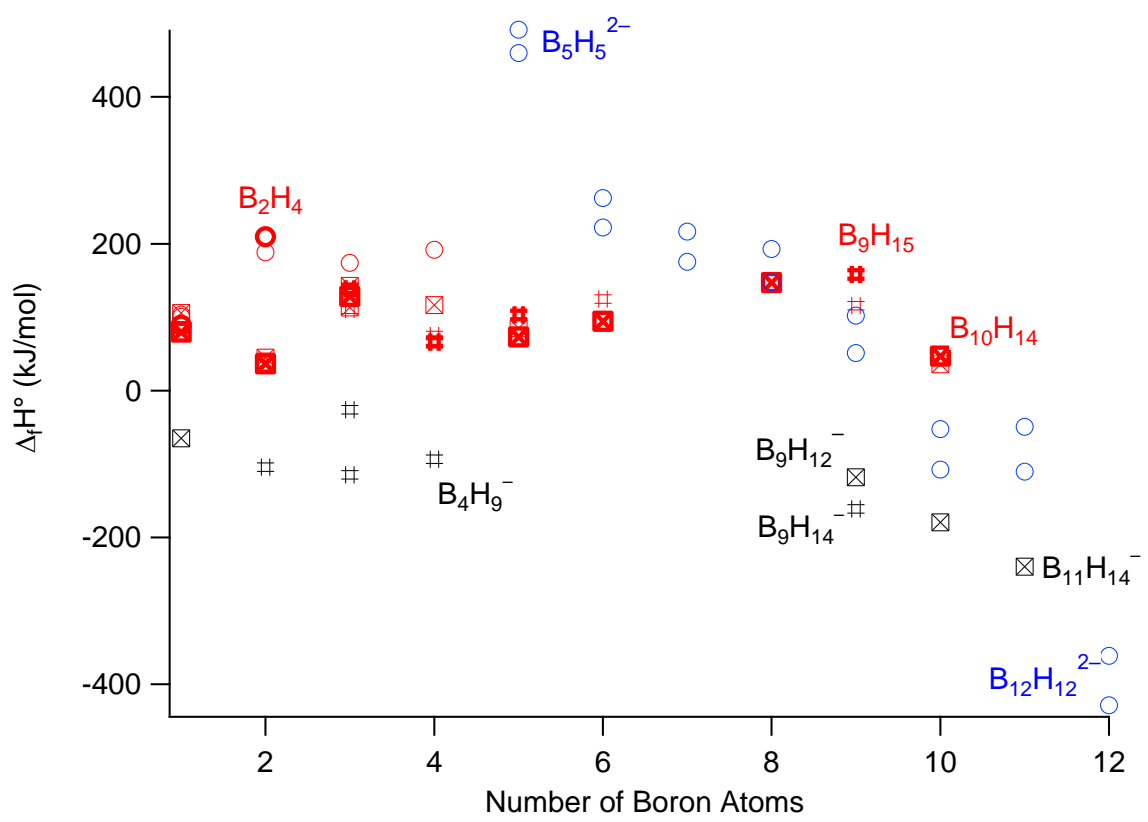

Figure 2. Experimental (bold) and theoretical formation enthalpy values for neutral (red) monoanionic (black) and dianionic (blue) species. Closo species, circles; nido, \#; arachno, crossed squares. Data from [69-72,74-76]. For closo ions $\mathrm{B}_{\mathrm{n}} \mathrm{H}_{\mathrm{n}}{ }^{2-}$, data (blue circles) from 2 different studies [69,72] reveal systematic differences. All monoanionic species (in black) have negative formation enthalpies, while all neutral boranes (in red) have positive formation enthalpy.

Figure 2 shows that the experimental formation enthalpies of neutral species are all positive [74], with values ranging from $36 \mathrm{~kJ} / \mathrm{mol}$ (for $\mathrm{B}_{2} \mathrm{H}_{6}$ ) to $210 \mathrm{~kJ} / \mathrm{mol}$ for $\left(\mathrm{B}_{2} \mathrm{H}_{4}\right)$. Gas phase reaction

$$
2 \mathrm{~B}_{2} \mathrm{H}_{6} \rightarrow \mathrm{B}_{4} \mathrm{H}_{10}+\mathrm{H}_{2}
$$

has an enthalpy change of $66.1-2 \times 36.4=-6.7 \mathrm{~kJ} / \mathrm{mol}$, and shows that increasing the number of boron atoms in the cluster can be thermodynamically favorable for neutral species. Other reactions towards larger hydroboranes may become favorable at higher temperatures from the liberation of hydrogen. The first theoretical studies of enthalpy changes for reactions of neutral boranes were reported by M.L. McKee in 1990 [70], who showed that a sequence of $\mathrm{BH}_{3}$ additions followed by $\mathrm{H}_{2}$ elimination from $\mathrm{B}_{2} \mathrm{H}_{6}$ to $\mathrm{B}_{6} \mathrm{H}_{10}$ is overall exothermic, but with two less stable reaction intermediates $\left(\mathrm{B}_{3} \mathrm{H}_{9}\right.$ and $\left.\mathrm{B}_{4} \mathrm{H}_{8}\right)$ that can act as barrier steps for the kinetics. Figure 2 shows that anionic species with 9-12 boron atoms are the most stable, which indicates that there is a thermodynamic driving force towards these anions. The most stable species in this figure is the closo $\mathrm{B}_{12} \mathrm{H}_{12}{ }^{2-}$ ion, and its stability is related to its 3-dimensional aromaticity [6]. The formation enthalpy of $\mathrm{B}_{12} \mathrm{H}_{12}{ }^{2-}$ in the gas phase was estimated to be between -325.5 and $-428.6 \mathrm{~kJ} / \mathrm{mol}$ according to different theoretical studies $[72,75,76]$. One key intermediate in the overall dehydrogenation reactions of $\mathrm{BH}_{4}{ }^{-}$appears to be ion $\mathrm{B}_{3} \mathrm{H}_{8}{ }^{-}$, which is discussed in the next section. 


\section{Formation and Reactions of $\mathrm{B}_{3} \mathrm{H}_{8}{ }^{-}$}

As mentioned above, the formation of $\mathrm{Mg}\left(\mathrm{B}_{3} \mathrm{H}_{8}\right)_{2}$ was observed during the decomposition of $\mathrm{Mg}\left(\mathrm{BH}_{4}\right)_{2}$ under dynamic vacuum [54,77], and $\mathrm{Y}\left(\mathrm{B}_{3} \mathrm{H}_{8}\right)_{3}$ was obtained after heating $\mathrm{Y}\left(\mathrm{BH}_{4}\right)_{3}$ under hydrogen pressure of 1-10 bar [78]. There are several reports in the literature on the synthesis of $\mathrm{B}_{3} \mathrm{H}_{8}{ }^{-}$that highlight that various routes can lead to this ion. Starting from diborane under strongly reducing conditions, dianion $\mathrm{B}_{2} \mathrm{H}_{6}{ }^{2-}$ was reported to form $[62,79]$

$$
2 \mathrm{~B}_{2} \mathrm{H}_{6}+2 \mathrm{C}_{8} \mathrm{H}_{10}{ }^{-} \rightarrow\left[\mathrm{BH}_{3}{ }^{2-}\right]+\mathrm{BH}_{3}+2 \mathrm{C}_{8} \mathrm{H}_{10} \rightarrow\left[\mathrm{B}_{2} \mathrm{H}_{6}{ }^{2-}\right]+2 \mathrm{C}_{8} \mathrm{H}_{10}
$$

$\mathrm{BH}_{3}{ }^{2-}$ and $\mathrm{B}_{2} \mathrm{H}_{6}{ }^{2-}$ intermediates were identified by NMR. The reaction of $\mathrm{B}_{2} \mathrm{H}_{6}{ }^{2-}$ with additional diborane yields $\mathrm{B}_{3} \mathrm{H}_{8}{ }^{-}+\mathrm{BH}_{4}{ }^{-}$, and no further intermediate was observed:

$$
\mathrm{B}_{2} \mathrm{H}_{6}+\mathrm{B}_{2} \mathrm{H}_{6}^{2-} \rightarrow \mathrm{B}_{3} \mathrm{H}_{8}^{-}+\mathrm{BH}_{4}^{-}
$$

Another reaction observed was the reaction of potassium metal with $\mathrm{THF}^{\mathrm{B}} \mathrm{BH}_{3}$ [80].

$$
2 \mathrm{~K}+4 \text { THF. } \mathrm{BH}_{3} \rightarrow 2 \mathrm{~K}^{+}+\mathrm{B}_{3} \mathrm{H}_{8}^{-}+\mathrm{BH}_{4}^{-}
$$

Beall and Gaines [62] argue that also in this case, $\mathrm{B}_{2} \mathrm{H}_{6}{ }^{2-}$ is the reaction intermediate, which can then react with THF- $\mathrm{BH}_{3}$ to form either $\mathrm{B}_{2} \mathrm{H}_{5}{ }^{-}+\mathrm{BH}_{4}{ }^{-}$with the addition of the 4th THF. $\mathrm{BH}_{3} \mathrm{~B}_{3} \mathrm{H}_{8}{ }^{-}$or first with THF- $\mathrm{BH}_{3}$ the ion $\mathrm{B}_{3} \mathrm{H}_{9}{ }^{2-}$, which then reacts with THF. $\mathrm{BH}_{3}$ to yield $\mathrm{B}_{3} \mathrm{H}_{8}{ }^{-}+\mathrm{BH}_{4}{ }^{-}$. $\mathrm{B}_{3} \mathrm{H}_{8}{ }^{-}$can also be formed from the reaction of $\mathrm{BH}_{4}{ }^{-}$ with diborane [81]:

$$
\begin{gathered}
\mathrm{BH}_{4}{ }^{-}+\mathrm{B}_{2} \mathrm{H}_{6} \rightarrow \mathrm{B}_{3} \mathrm{H}_{8}{ }^{-}+\mathrm{H}_{2} \\
\mathrm{BH}_{4}{ }^{-}+\mathrm{B}_{2} \mathrm{H}_{6} \rightarrow \mathrm{BH}_{3}+\mathrm{B}_{2} \mathrm{H}_{7}^{-} \rightarrow \mathrm{BH}_{3}+\mathrm{B}_{2} \mathrm{H}_{5}{ }^{-}+\mathrm{H}_{2} \rightarrow \mathrm{B}_{3} \mathrm{H}_{8}{ }^{-}+\mathrm{H}_{2} \\
\mathrm{BH}_{4}{ }^{-}+\mathrm{B}_{2} \mathrm{H}_{6} \rightarrow \mathrm{BH}_{3}+\mathrm{B}_{2} \mathrm{H}_{7}{ }^{-} \rightarrow \mathrm{B}_{3} \mathrm{H}_{10}{ }^{-} \rightarrow \mathrm{B}_{3} \mathrm{H}_{8}{ }^{-}+\mathrm{H}_{2}
\end{gathered}
$$

This reaction can proceed either via $\mathrm{B}_{2} \mathrm{H}_{7}{ }^{-}$(hydride transfer) and $\mathrm{B}_{3} \mathrm{H}_{10}{ }^{-}\left(\mathrm{BH}_{3}\right.$ addition) followed by $\mathrm{H}_{2}$ detachment or via $\mathrm{B}_{2} \mathrm{H}_{7}{ }^{-}$, which first loses $\mathrm{H}_{2}$ to form $\mathrm{B}_{2} \mathrm{H}_{5}{ }^{-}$, which then adds $\mathrm{BH}_{3}$. The efficient synthesis of alkali metal octahydrotriborates $(\mathrm{M}=\mathrm{Na}$, $\mathrm{K}, \mathrm{Rb}, \mathrm{Cs}$ ) from the reaction of $\mathrm{MBH}_{4}$ with 2 equivalents of dimethyl sulfide borane was reported [82]. The formation of ion $\mathrm{B}_{2} \mathrm{H}_{7}{ }^{-}$was observed by NMR for the reaction of $\mathrm{LiBH}_{4}$ with THF. $\mathrm{BH}_{3}$ in THF [83], and during the solvothermal reaction of $\mathrm{BH}_{4}{ }^{-}$with $\mathrm{CH}_{2} \mathrm{Cl}_{2}$ at $70{ }^{\circ} \mathrm{C}$ [84]. The reaction of $\mathrm{BD}_{4}{ }^{-}$requires higher temperatures $\left(90^{\circ} \mathrm{C}\right)[84]$, which suggests that the rate-determining reaction step is associated with the breaking of a boron-hydrogen (deuterium) bond, which could be the formation of a reactive Lewis adduct of $\mathrm{BH}_{3}$ from $\mathrm{BH}_{4}{ }^{-}$, which then reacts with other $\mathrm{BH}_{4}{ }^{-}$to form $\mathrm{B}_{2} \mathrm{H}_{7}{ }^{-}$etc., as outlined above.

Once formed, $\mathrm{B}_{3} \mathrm{H}_{8}{ }^{-}$can further react to yield $\mathrm{B}_{9}$ to $\mathrm{B}_{12}$ hydroborate anions. Using the DFT calculation formation enthalpies of $\mathrm{B}_{9} \mathrm{H}_{14}{ }^{-}, \mathrm{B}_{3} \mathrm{H}_{8}{ }^{-}$and $\mathrm{BH}_{4}{ }^{-}$[71], for the gas phase reactions, one obtains

$$
\begin{gathered}
4 \mathrm{~B}_{3} \mathrm{H}_{8}{ }^{-} \rightarrow \mathrm{B}_{9} \mathrm{H}_{14}{ }^{-}+3 \mathrm{BH}_{4}{ }^{-}+3 \mathrm{H}_{2} \\
4 \mathrm{~B}_{3} \mathrm{H}_{8}{ }^{-} \rightarrow \mathrm{B}_{10} \mathrm{H}_{10}{ }^{2-}+2 \mathrm{BH}_{4}{ }^{-}+9 \mathrm{H}_{2}
\end{gathered}
$$

exothermic reaction enthalpy values of -413 and $-49.8 \mathrm{~kJ} / \mathrm{mol}$, respectively, and a strong entropy increase that even further favors the reaction at higher temperatures. These spontaneous overall reaction enthalpies also explain why potential reaction intermediates with 6 to 8 boron atoms are practically not observed. The simultaneous production of $\mathrm{BH}_{4}{ }^{-}$in these reactions adds a thermodynamic driving force (as the formation enthalpy of $\mathrm{BH}_{4}{ }^{-}$is negative) for these reactions.

In the presence of hydrides, Grinderslev et al. [85] observed the following decomposition reaction at 150 and $200{ }^{\circ} \mathrm{C}$ of $\mathrm{KB}_{3} \mathrm{H}_{8}$ under 380 bar of $\mathrm{H}_{2}$ :

$$
\mathrm{KB}_{3} \mathrm{H}_{8}+2 \mathrm{KH} \rightarrow \mathrm{KBH}_{4}+\mathrm{K}_{2} \mathrm{~B}_{12} \mathrm{H}_{12}+\mathrm{K}_{2} \mathrm{~B}_{10} \mathrm{H}_{10}+\mathrm{K}_{2} \mathrm{~B}_{9} \mathrm{H}_{9}
$$


As shown above, heating solvent-free $\mathrm{Mg}\left(\mathrm{B}_{3} \mathrm{H}_{8}\right)_{2}+4 \mathrm{MgH}_{2}$ either with or without $\mathrm{H}_{2}$ gas results in up to $88 \%$ back conversion to $\mathrm{Mg}\left(\mathrm{BH}_{4}\right)_{2}$ with some $\mathrm{MgB}_{12} \mathrm{H}_{12}$ [60]. These results show that $\mathrm{B}_{3} \mathrm{H}_{8}{ }^{-}$can react in many different ways to either form larger boron hydride clusters or regenerate $\mathrm{BH}_{4}{ }^{-}$. This can be exploited, for instance, to achieve the direct synthesis of $\mathrm{B}_{10} \mathrm{H}_{10}{ }^{2-}$ and $\mathrm{B}_{12} \mathrm{H}_{12}{ }^{2-}$ to prepare solid ionic conductors such as $\mathrm{Na}_{4}\left(\mathrm{~B}_{10} \mathrm{H}_{10}\right)\left(\mathrm{B}_{12} \mathrm{H}_{12}\right)$, as demonstrated by Gigante et al. [86]. This synthesis starts with the conversion of $\mathrm{NaBH}_{4}$ into $\left(\mathrm{Et}_{4} \mathrm{~N}\right) \mathrm{BH}_{4}$, which reacts solvothermally with $\mathrm{CH}_{2} \mathrm{Cl}_{2}$ to form $\left(\mathrm{Et}_{4} \mathrm{~N}\right) \mathrm{B}_{3} \mathrm{H}_{8}$. $\left(\mathrm{Et}_{4} \mathrm{~N}\right) \mathrm{B}_{3} \mathrm{H}_{8}$ is then heated in toluene to $185^{\circ} \mathrm{C}$ to form a mixture of $\left(\mathrm{Et}_{4} \mathrm{~N}\right)_{2} \mathrm{~B}_{10} \mathrm{H}_{10}$ and $\left(\mathrm{Et}_{4} \mathrm{~N}\right)_{2} \mathrm{~B}_{12} \mathrm{H}_{12}$, which can then either be separated by fractional crystallization or directly converted with sodium tetraphenylborate into ionic conductor $\mathrm{Na}_{4}\left(\mathrm{~B}_{10} \mathrm{H}_{10}\right)\left(\mathrm{B}_{12} \mathrm{H}_{12}\right)$.

\section{Closoborates and Related Species as Solid Ionic Conductors}

Solid ionic conductors for lithium or sodium batteries allow for avoiding the use of a flammable organic electrolyte and are thus expected to considerably improve the safety of batteries. A good solid electrolyte must fulfill several empirical criteria, according to [87]:

- "open structure" with a low coordination number of the mobile ion;

- $\quad$ The presence of structural phase transitions at low pressure. In the case of AgI, the ambient pressure wurtzite structure (space group $\mathrm{P} 6_{3} \mathrm{mc}$ ) transforms at $3 \mathrm{kbar}$ and $315 \mathrm{~K}$ into a $\mathrm{NaCl}$ structure (space group $\mathrm{Fm}-3 \mathrm{~m}$ ), thus going from a rather covalent network with coordination number 4 to a rather ionic structure with coordination number 6 . The associated charge fluctuations between ions can potentially be coupled to vibrational motions and thus dynamically favor ionic conduction.

For practical applications, the conductivity of the material should be higher than $1 \mathrm{mS} / \mathrm{cm}$. Further, the material should have high chemical and thermal stability, and a high electrochemical stability window. Additionally, it must be electronically insulating to avoid battery self-discharge or shortage. Further, the electrolyte should be deformable in order to accommodate the volume changes of anode and cathode materials upon lithium or sodium insertion and removal. This can thus limit the formation of fractures that reduce the performance of the battery. Lastly, the material should not be toxic and be cheap enough for the considered applications.

The discovery of superionic conductivity in the high-temperature phases of $\mathrm{LiBH}_{4}$ [88] and $\mathrm{Na}_{2} \mathrm{~B}_{12} \mathrm{H}_{12}$ [29] has stimulated new research for similar compounds with high ionic conductivity at lower temperatures. These compounds include closo-hydroborates, nidohydroborates $\left(\mathrm{B}_{11} \mathrm{H}_{14}{ }^{-}\right)$, and closo-hydrocarborates $\left(\mathrm{CB}_{9} \mathrm{H}_{10}{ }^{-}, \mathrm{CB}_{11} \mathrm{H}_{12}{ }^{-}\right)$. Ions $\mathrm{B}_{10} \mathrm{H}_{10}{ }^{2-}$ and $\mathrm{B}_{12} \mathrm{H}_{12}{ }^{2-}$ are not very toxic. Mutterties et al. [89] reported $\mathrm{LD}_{50}$ values for $\mathrm{Na}_{2} \mathrm{~B}_{10} \mathrm{H}_{10}$ and $\mathrm{Na}_{2} \mathrm{~B}_{12} \mathrm{H}_{12}$ administered orally to rats to be around or higher than $7.5 \mathrm{~g} / \mathrm{kg}$ of body weight for both compounds.

The crystal chemistry of inorganic hydroborates except $\mathrm{BH}_{4}{ }^{-}$was recently presented in detail [90], while the crystal chemistry of salts with $\mathrm{BH}_{4}{ }^{-}$was addressed in an earlier review [18]: "All nonmolecular hydroborate crystal structures can be derived by simple deformation of the close-packed anionic lattices, i.e., cubic close packing (ccp) and hexagonal close packing (hcp), or bodycentered cubic (bcc), by filling tetrahedral or octahedral sites" [90]. This observation can be illustrated considering group-subgroup relationships of encountered crystal structures, as illustrated in Figure 3 for some relevant compounds [90-102]. Crystal packing is governed by large anions, leaving in some space groups empty cationic sites, which, of course, favor ionic conduction. For instance, $\beta-\mathrm{Na}_{2} \mathrm{~B}_{12} \mathrm{H}_{12}$ crystallizes in the Pm- $3 \mathrm{n}$ space group with a statistical population of 6 sites occupied by $4 \mathrm{Na}^{+}$ions.

Perturbations of the anionic sublattice further allow for stabilizing the conductive phase at lower temperatures. This was first demonstrated for solid solutions of $\mathrm{LiBH}_{4}$ with $\mathrm{LiBr}$ and LiI [103]. Phase stability and ionic conductivity in mixed $\mathrm{LiBH}_{4}-\mathrm{LiX}(\mathrm{X}=\mathrm{Cl}, \mathrm{Br})$ was recently studied in detail [104]. Perturbations of the structure by ball milling or partial substitution was demonstrated for $\mathrm{Na}_{2} \mathrm{~B}_{12} \mathrm{H}_{12}$ with a partial introduction of iodine ions in the closo-hydroborate [105]. In a further step, solid solutions of closo-hydroborate and 
closo-carbahydroborates, and solid solutions of nido-hydroborates with closo-hydroborates were studied [106-112]. Representative examples of mixed borate ionic conductors are shown in Table 1.

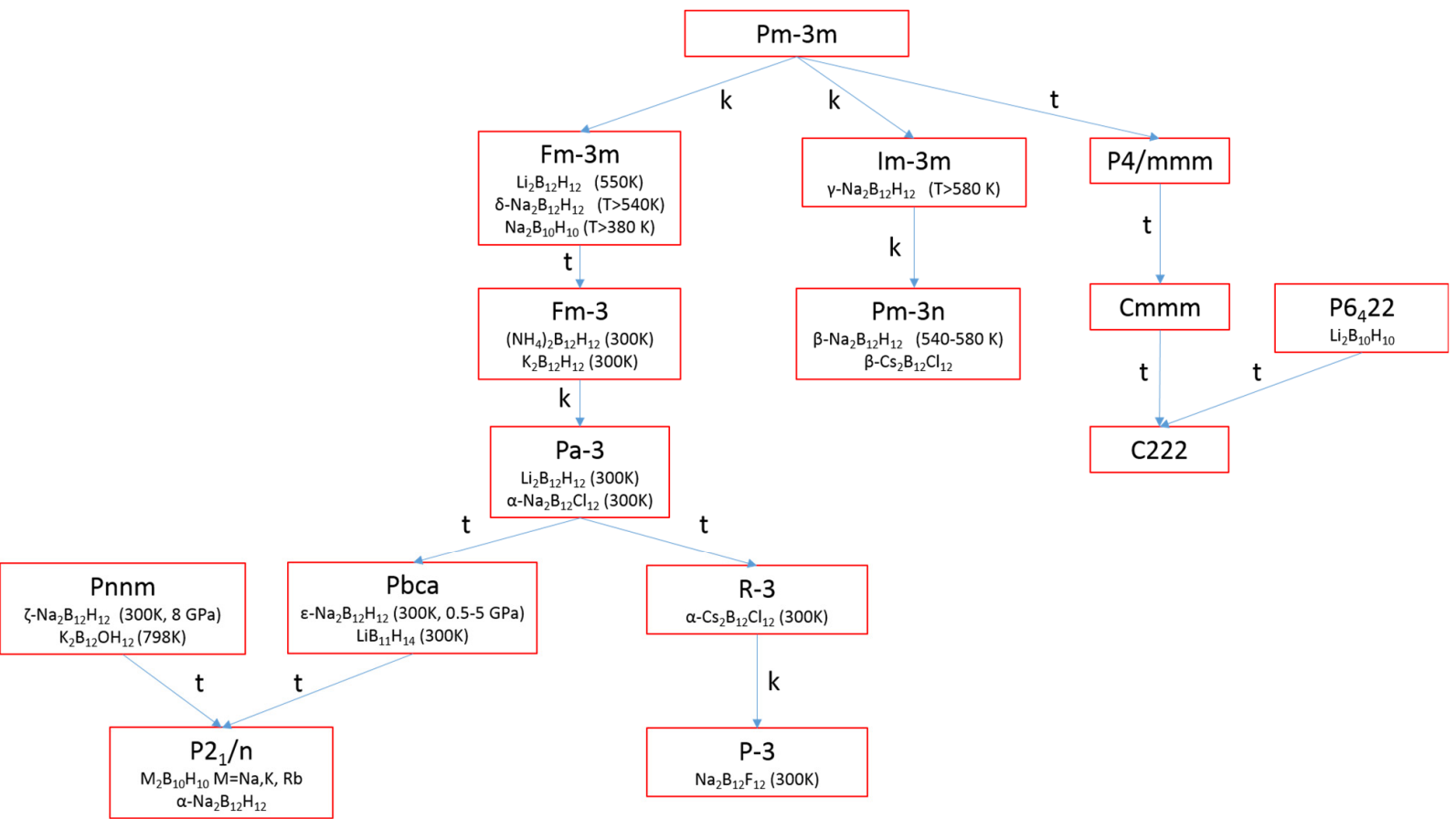

Figure 3. Group-subgroup relationships between space groups (in Herrmann-Mauguin notation) of closo-hydro borates and some closo-halogeno borates. t, "translationengleich" subgroups; k, “klassengleich" subgroups.

Table 1. Examples of ionic conductivity in mixed borate salts.

\begin{tabular}{cccc}
\hline Compound & Temperature & Conductivity & Reference \\
\hline $0.7 \mathrm{Li}\left(\mathrm{CB}_{9} \mathrm{H}_{10}\right)-0.3 \mathrm{Li}\left(\mathrm{CB}_{11} \mathrm{H}_{12}\right)$ & $298 \mathrm{~K}$ & $6.7 \mathrm{mS} / \mathrm{cm}$ & {$[106]$} \\
\hline $\mathrm{Li}_{2}\left(\mathrm{~B}_{11} \mathrm{H}_{14}\right)\left(\mathrm{CB}_{11} \mathrm{H}_{12}\right)$ & $298 \mathrm{~K}$ & $0.11 \mathrm{mS} / \mathrm{cm}$ & {$[107]$} \\
\hline $\mathrm{Li}_{3}\left(\mathrm{~B}_{11} \mathrm{H}_{14}\right)\left(\mathrm{CB}_{11} \mathrm{H}_{12}\right)_{2}$ & $298 \mathrm{~K}$ & $1.1 \mathrm{mS} / \mathrm{cm}$ & {$[107]$} \\
\hline $\mathrm{Na}_{3}\left(\mathrm{CB}_{11} \mathrm{H}_{12}\right)\left(\mathrm{B}_{12} \mathrm{H}_{12}\right)$ & $298 \mathrm{~K}$ & $2 \mathrm{mS} / \mathrm{cm}$ & {$[108]$} \\
\hline $\mathrm{Na}_{4}\left(\mathrm{CB}_{11} \mathrm{H}_{12}\right)_{2}\left(\mathrm{~B}_{12} \mathrm{H}_{12}\right)$ & $298 \mathrm{~K}$ & $2 \mathrm{mS} / \mathrm{cm}$ & {$[108]$} \\
\hline $\mathrm{Na}_{4}\left(\mathrm{~B}_{10} \mathrm{H}_{10}\right)\left(\mathrm{B}_{12} \mathrm{H}_{12}\right)$ & $298 \mathrm{~K}$ & $0.9 \mathrm{mS} / \mathrm{cm}$ & {$[109]$} \\
\hline $\mathrm{Na}_{2}\left(\mathrm{~B}_{10} \mathrm{H}_{10}\right)-3 \mathrm{Na}_{2}\left(\mathrm{~B}_{12} \mathrm{H}_{12}\right)$ & $298 \mathrm{~K}$ & $0.34 \mathrm{mS} / \mathrm{cm}$ & {$[110]$} \\
\hline $\mathrm{Na}_{\mathrm{x}+2 \mathrm{y}}\left(\mathrm{B}_{11} \mathrm{H}_{14}\right)_{\mathrm{x}}\left(\mathrm{B}_{12} \mathrm{H}_{12}\right)_{\mathrm{y}}$ & $298 \mathrm{~K}$ & $3-4 \mathrm{mS} / \mathrm{cm}$ & {$[111]$} \\
\hline
\end{tabular}

The mechanism of ionic conduction in these compounds is related to the dynamical properties of the borohydride or carbohydride ions. These properties can be addressed using NMR [113] and neutron techniques [114], in conjunction with temperature-dependent conductivity and $\mathrm{X}$-ray diffraction, and are supported by theoretical calculations $[76,77,88]$. A detailed study of ionic conductor $\mathrm{Na}_{4}\left(\mathrm{~B}_{12} \mathrm{H}_{12}\right)\left(\mathrm{B}_{10} \mathrm{H}_{10}\right)$ [115] with all these techniques revealed 3 different regimes with increasing temperature. Below $-50{ }^{\circ} \mathrm{C}$, conductivity remains very low. Above this temperature, an apparent activation energy of $0.6 \mathrm{eV}$ was found, related to significant couplings of anionic and cationic motions. Above $70{ }^{\circ} \mathrm{C}$, activation energy decreases to $0.37 \mathrm{eV}$, as thermal energy leads to noncorrelated ionic motions.

One important aspect of solid ionic conductors is their electrochemical stability, which is a critical limit for a reversible battery application. Asakura et al. [116] developed a linear sweep voltammetry method to reliably measure the electrochemical stability of borohydride-based solid electrolytes. The measured oxidative stability of $\mathrm{LiBH}_{4}$ of $2.0 \mathrm{~V}$ 
vs. $\mathrm{Li}^{+} / \mathrm{Li}$ was significantly smaller than that in initial reports claiming a stability of up to $5 \mathrm{~V}$ [117]. For $\mathrm{Na}_{4}\left(\mathrm{~B}_{12} \mathrm{H}_{12}\right)\left(\mathrm{B}_{10} \mathrm{H}_{10}\right)$, two oxidation onsets at 3.02 and $3.22 \mathrm{~V} v \mathrm{vs}$. $\mathrm{Na}^{+} / \mathrm{Na}$ were tentatively assigned to the onset of decomposition of the less stable $\left[\mathrm{B}_{10} \mathrm{H}_{10}\right]^{2-}$ and more stable $\left[\mathrm{B}_{12} \mathrm{H}_{12}\right]^{2-}$ ions, respectively [116]. Closo-carborane ions are even more stable, as for $\mathrm{Na}_{4}\left(\mathrm{CB}_{11} \mathrm{H}_{12}\right)_{2}\left(\mathrm{~B}_{12} \mathrm{H}_{12}\right)$, where a large anodic current was observed above $4 \mathrm{~V}$ vs. $\mathrm{Na}^{+} / \mathrm{Na}$, together with a small onset at $2.93 \mathrm{~V}$. For $\mathrm{Li}_{2}\left(\mathrm{CB}_{9} \mathrm{H}_{10}\right)\left(\mathrm{CB}_{11} \mathrm{H}_{12}\right)$, the onset of decomposition was observed at $2.86 \mathrm{~V} \mathrm{vs}$. $\mathrm{Li}^{+} / \mathrm{Li}$ [116]. Nido-borates are electrochemically less stable. The oxidative stability limit for $\mathrm{Na}_{5}\left(\mathrm{~B}_{11} \mathrm{H}_{14}\right)\left(\mathrm{B}_{12} \mathrm{H}_{12}\right)_{2}$ was $2.6 \mathrm{~V}$ vs. $\mathrm{Na}^{+} / \mathrm{Na}$, and for $\mathrm{LiB}_{11} \mathrm{H}_{14}, 2.6 \mathrm{~V}$ vs. $\mathrm{Li}^{+} / \mathrm{Li}$ [107].

These developments have also led to several all-solid-state battery prototypes based on these mixed borate ionic conductors. Duchêne et al. [118] presented a $3 \mathrm{~V}$ sodium battery using $\mathrm{Na}_{4}\left(\mathrm{~B}_{12} \mathrm{H}_{12}\right)\left(\mathrm{B}_{10} \mathrm{H}_{10}\right)$, and Murgia et al. [119] showed Na stripping/plating over $>500 \mathrm{~h}$ in a Na cell with $\mathrm{Na}_{4}\left(\mathrm{CB}_{11} \mathrm{H}_{12}\right)_{2}\left(\mathrm{~B}_{12} \mathrm{H}_{12}\right)$. Recently, Asakura et al. [120] demonstrated a $4 \mathrm{~V}$ sodium battery with the same solid-state conductor, $\mathrm{Na}_{4}\left(\mathrm{CB}_{11} \mathrm{H}_{12}\right)_{2}\left(\mathrm{~B}_{12} \mathrm{H}_{12}\right)$. These results show that closo-hydroborates and their derivatives are very promising materials for chemically and electrochemically stable all-solid-state ionic conductors.

\section{Conclusions}

In the last 20 years, many studies on borohydride species have considerably increased our knowledge on the properties of these materials. For hydrogen storage applications, the kinetics and reversibility of the dehydrogenation reactions remain a major challenge for practical applications. The chemistry of borohydrides from $\mathrm{BH}_{4}{ }^{-}$to $\mathrm{B}_{12} \mathrm{H}_{12}{ }^{2-}$ in the gas phase and in solution has been theoretically and experimentally addressed; however, in solids, these studies are very challenging, as structural data of potential reaction intermediates such as $\mathrm{Mg}\left(\mathrm{B}_{3} \mathrm{H}_{8}\right)_{2}$ are elusive, and not all intermediates can be observed. If the reaction intermediates are amorphous, $\mathrm{X}$-ray diffraction cannot be used, and theoretical approaches can lead to many different potential structures. The presence of additional hydrides or of Lewis bases such as THF, as shown for the reactions of $\mathrm{KB}_{3} \mathrm{H}_{8}$ and $\mathrm{Mg}\left(\mathrm{B}_{3} \mathrm{H}_{8}\right)_{2}$, strongly modifies the reaction products upon heating. We are thus still very far from a full microscopic understanding of these hydrogenation-dehydrogenation reactions and in the search for optimal catalysts for these processes.

For hydrogen storage, $\mathrm{B}_{3} \mathrm{H}_{8}{ }^{-}$is an interesting species that can be rehydrogenated back to $\mathrm{BH}_{4}{ }^{-}$. Even though only $25 \%$ of the hydrogen is available for this reversible hydrogen storage, the temperatures (less than $200{ }^{\circ} \mathrm{C}$ ) and kinetics of these reactions approach practical conditions.

The closo-hydroborate ions that are formed and identified as intermediates of dehydrogenation reactions have found new and very promising applications as solid-state ionic conductors, as they present many very favorable properties for this use. The recent demonstration of a $4 \mathrm{~V}$ all-solid-state battery using solid sodium electrolyte $\mathrm{Na}_{4}\left(\mathrm{CB}_{11} \mathrm{H}_{12}\right)_{2}\left(\mathrm{~B}_{12} \mathrm{H}_{12}\right)$ [120] highlights this potential. Whether compounds such as $\mathrm{Mg}\left(\mathrm{B}_{10} \mathrm{H}_{10}\right)$, which can be obtained starting from $\mathrm{Mg}\left(\mathrm{BH}_{4}\right)_{2} .2 \mathrm{THF}$, are applicable for new $\mathrm{Mg}$-based batteries remains to be demonstrated. In the preparation of these closo-hydroborates and their derivatives, starting from $\mathrm{BH}_{4}{ }^{-}$ instead of neutral boranes, has the great advantage to reduce the toxicity of the reactants. $\mathrm{B}_{2} \mathrm{H}_{6}$, $\mathrm{B}_{5} \mathrm{H}_{9}$ and $\mathrm{B}_{10} \mathrm{H}_{14}$ are highly toxic and thereby not really suitable for industrial production processes of closo-hydroborates at a higher scale. Thus, boron-hydrogen compounds have a future for new green energy applications.

Funding: This research was funded by the Swiss National Science Foundation, grant number 200020_182494.

Institutional Review Board Statement: Not applicable.

Informed Consent Statement: Not applicable.

Data Availability Statement: Not applicable.

Conflicts of Interest: The author declares no conflict of interest. 


\section{References}

1. Stock, A. The Hydrides of Boron and Silicon; Cornell University Press: New York, NY, USA, 1933.

2. Martin, D.R. The Development of Borane Fuels. J. Chem. Educ. 1959, 36, 208-214. [CrossRef]

3. Baier, M.J.; Veeraraghavan Ramachandran, P.; Son, S.F. Characterization of the Hypergolic Ignition Delay of Ammonia Borane. J. Propuls. Power 2019, 35, 182-189. [CrossRef]

4. Zhang, Z.; Zhao, Z.; Wang, B.; Zhang, J. Boron based hypergolic ionic liquids: A review. Green Energy Environ. $2020,6,794-822$. [CrossRef]

5. Huang, Z.; Wang, S.; Dewhurst, R.D.; Ignat'ev, N.V.; Finze, M.; Braunschweig, H. Boron: Its Role in Energy-Related Processes and Applications. Angew. Chem. Int. Ed. 2020, 59, 8800-8816. [CrossRef]

6. Zhao, X.; Yang, Z.; Chen, H.; Wang, Z.; Zhou, X.; Zhang, H. Progress in three-dimensional aromatic-like closo-dodecaborate. Coord. Chem. Rev. 2021, 444, 214042. [CrossRef]

7. Stauber, J.M.; Schwan, J.; Zhang, X.; Axtell, J.C.; Jung, D.; McNicholas, B.J.; Oyala, P.H.; Martinolich, A.J.; Winkler, J.R.; See, K.A.; et al. A Super-Oxidized Radical Cationic Icosahedral Boron Cluster. J. Am. Chem. Soc. 2020, 142, 12948-12953. [CrossRef]

8. Tu, D.; Yan, H.; Poater, J.; Solà, M. The nido-Cage $\cdots \pi$ Bond: A Non-covalent Interaction between Boron Clusters and Aromatic Rings and Its Applications. Angew. Chemie Int. Ed. 2020, 59, 9018-9025. [CrossRef] [PubMed]

9. Alamón, C.; Dávila, B.; García, M.F.; Sánchez, C.; Kovacs, M.; Trias, E.; Barbeito, L.; Gabay, M.; Zeineh, N.; Gavish, M.; et al. Sunitinib-Containing Carborane Pharmacophore with the Ability to Inhibit Tyrosine Kinases Receptors FLT3, KIT and PDGFR- $\beta$, Exhibits Powerful In Vivo Anti-Glioblastoma Activity. Cancers 2020, 12, 3423. [CrossRef] [PubMed]

10. Ali, F.; S Hosmane, N.; Zhu, Y. Boron Chemistry for Medical Applications. Molecules 2020, 25, 828. [CrossRef]

11. Stockmann, P.; Gozzi, M.; Kuhnert, R.; Sárosi, M.B.; Hey-Hawkins, E. New keys for old locks: Carborane-containing drugs as platforms for mechanism-based therapies. Chem. Soc. Rev. 2019, 48, 3497-3512. [CrossRef]

12. Bogdanovic, B.; Schwickardi, M. Ti-doped alkali metal aluminium hydrides as potential novel reversible hydrogen storage materials. J. Alloys Compd. 1997, 253-254, 1-9. [CrossRef]

13. Yang, J.; Sudik, A.; Wolverton, C.; Siegel, D.J. High capacity hydrogen storage materials: Attributes for automotive applications and techniques for materials discovery. Chem. Soc. Rev. 2010, 39, 656-675. [CrossRef]

14. Bellosta von Colbe, J.; Ares, J.-R.; Barale, J.; Baricco, M.; Buckley, C.; Capurso, G.; Gallandat, N.; Grant, D.M.; Guzik, M.N.; Jacob, I.; et al. Application of hydrides in hydrogen storage and compression: Achievements, outlook and perspectives. Int. J. Hydrog. Energy 2019, 44, 7780-7808. [CrossRef]

15. Schneemann, A.; White, J.L.; Kang, S.; Jeong, S.; Wan, L.F.; Cho, E.S.; Heo, T.W.; Prendergast, D.; Urban, J.J.; Wood, B.C.; et al. Nanostructured Metal Hydrides for Hydrogen Storage. Chem. Rev. 2018, 118, 10775-10839. [CrossRef]

16. Ohno, S.; Banik, A.; Dewald, G.F.; Kraft, M.A.; Krauskopf, T.; Minafra, N.; Till, P.; Weiss, M.; Zeier, W.G. Materials design of ionic conductors for solid state batteries. Prog. Energy 2020, 2, 022001. [CrossRef]

17. Paskevicius, M.; Jepsen, L.H.; Schouwink, P.; Černý, R.; Ravnsbæk, D.B.; Filinchuk, Y.; Dornheim, M.; Besenbacher, F.; Jensen, T.R. Metal borohydrides and derivatives-synthesis, structure and properties. Chem. Soc. Rev. 2017, 46, 1565-1634. [CrossRef]

18. Černý, R.; Schouwink, P. The crystal chemistry of inorganic metal borohydrides and their relation to metal oxides. Acta Cryst. 2015, B71, 619-640. [CrossRef]

19. Moussa, G.; Moury, R.; Demirci, U.B.; Sener, T.; Miele, P. Boron-based Hydrides for Chemical Hydrogen Storage. Int. J. Energy Res. 2013, 37, 825-842. [CrossRef]

20. Suárez-Alcántara, K.; Tena-Garcia, J.R.; Ricardo Guerrero-Ortiz, R. Alanates, a Comprehensive Review. Materials 2019, $12,2724$. [CrossRef]

21. Dobbins, T.A. Overview of the Structure-Dynamics-Function Relationships in Borohydrides for Use as Solid-State Electrolytes in Battery Applications. Molecules 2021, 26, 3239. [CrossRef] [PubMed]

22. Zavorotynska, O.; El-Kharbachi, A.; Deledda, S.; Hauback, B.C. Recent progress in magnesium borohydride $\mathrm{Mg}\left(\mathrm{BH}_{4}\right)_{2}$ : Fundamentals and applications for energy storage. Int. J. Hydrog. Energy 2016, 41, 14387-14403. [CrossRef]

23. Zhang, Y.; Majzoub, E.; Ozolinš, V.; Wolverton, C. Theoretical Prediction of Metastable Intermediates in the Decomposition of $\mathrm{Mg}\left(\mathrm{BH}_{4}\right)_{2}$. J. Phys. Chem. C 2012, 116, 10522-10528. [CrossRef]

24. Hwang, S.-J.; Bowman, R.C.; Reiter, J.W.; Rijssenbeek, J.; Soloveichik, G.L.; Zhao, J.-C.; Kabbour, H.; Ahn, C.C. NMR confirmation for formation of $\left[\mathrm{B}_{12} \mathrm{H}_{12}\right]^{2-}$ complexes during hydrogen desorption from metal borohydrides. J. Phys. Chem. C 2008, 112, 3164-3169. [CrossRef]

25. Golub, I.E.; Filippov, O.A.; Belkova, N.V.; Epstein, L.M.; Shubina, E.S. The Reaction of Hydrogen Halides with Tetrahydroborate Anion and Hexahydro-closo-hexaborate Dianion. Molecules 2021, 26, 3754. [CrossRef]

26. Voinova, V.V.; Selivanov, N.A.; Plyushchenko, I.V.; Vokuev, M.F.; Bykov, A.Y.; Klyukin, I.N.; Novikov, A.S.; Zhdanov, A.P.; Grigoriev, M.S.; Rodin, I.A.; et al. Fused 1,2-Diboraoxazoles Based on closo-Decaborate Anion-Novel Members of Diboroheterocycle Class. Molecules 2021, 26, 248. [CrossRef]

27. Andreichuk, E.P.; Anufriev, S.A.; Suponitsky, K.Y.; Sivaev, I.B. The First Nickelacarborane with closo-nido Structure. Molecules 2020, 25, 6009. [CrossRef] 
28. Klyukin, I.N.; Vlasova, Y.S.; Novikov, A.S.; Zhdanov, A.P.; Hagemann, H.R.; Zhizhin, K.Y.; Kuznetsov, N.T. B-F bonding and reactivity analysis of mono- and perfluoro-substituted derivatives of closo-borate anions $(6,10,12)$ : A computational study. Polyhedron 2022, 211, 115559. [CrossRef]

29. Udovic, T.J.; Matsuo, M.; Unemoto, A.; Verdal, N.; Stavila, V.; Skripov, A.V.; Rush, J.J.; Takamura, H.; Orimo, S. Sodium Superionic Conduction in $\mathrm{Na}_{2} \mathrm{~B}_{12} \mathrm{H}_{12}$. Chem. Commun. 2014, 50, 3750-3752. [CrossRef]

30. Duchêne, L.; Remhof, A.; Hagemann, H.; Battaglia, C. Status and prospects of hydroborate electrolytes for all-solid-state batteries. Energy Storage Mat. 2020, 26, 543-549. [CrossRef]

31. He, L.; Li, H.-W.; Hwang, S.-J.; Akiba, E. Facile Solvent-Free Synthesis of anhydrous alkali metal dodecaborate $\mathrm{M}_{2} \mathrm{~B}_{12} \mathrm{H}_{12}(\mathrm{M}=\mathrm{Li}$, Na, K). J. Phys. Chem. C 2014, 118, 6084-6089. [CrossRef]

32. Zhang, W.; Zhang, X.; Huang, Z.; Li, H.-W.; Gao, M.; Pan, H.; Liu, Y. Recent Development of Lithium Borohydride-Based Materials for Hydrogen Storage. Adv. Energy Sustain. Res. 2021, 2, 2100073. [CrossRef]

33. Filinchuk, Y.; Richter, B.; Jensen, T.R.; Dmitriev, V.; Chernyshov, D.; Hagemann, H. Porous and Dense Magnesium Borohydride Frameworks: Synthesis, Stability, and Reversible Absorption of Guest Species. Angew. Chem. Int. Ed. 2011, 50, 11162-11166. [CrossRef] [PubMed]

34. Yang, J.; Zhang, X.; Zheng, J.; Song, P.; Li, X. Decomposition pathway of $\mathrm{Mg}\left(\mathrm{BH}_{4}\right)_{2}$ under pressure: Metastable phases and thermodynamic parameters. Scr. Mater. 2011, 64, 225-228. [CrossRef]

35. Vitillo, J.G.; Bordiga, S.; Baricco, M. Spectroscopic and Structural Characterization of Thermal Decomposition of $\left.\gamma-\mathrm{Mg}_{(\mathrm{BH}}\right)_{2}$ : Dynamic Vacuum versus $\mathrm{H}_{2}$ Atmosphere. J. Phys. Chem. C 2015, 119, 25340-25351. [CrossRef]

36. Wang, X.; Xiao, X.; Zheng, J.; Yao, Z.; Zhang, M.; Huang, X.; Chen, L. Insights into magnesium borohydride dehydrogenation mechanism from its partial reversibility under moderate conditions. Mater. Today Energy 2020, 18, 100552. [CrossRef]

37. Crociani, L.; Rossetto, G.; Kaciulis, S.; Mezzi, A.; El-Habra, N.; Palmieri, V. Study of Magnesium Boride Films Obtained from $\mathrm{Mg}\left(\mathrm{BH}_{4}\right)_{2}$ by CVD. Chem. Vap. Depos. 2007, 13, 414-419. [CrossRef]

38. Kim, D.Y.; Yang, Y.; Abelson, J.R.; Girolami, G.S. Volatile magnesium octahydrotriborate complexes as potential CVD Precursors to $\mathrm{MgB}_{2}$. Synthesis and Characterization of $\mathrm{Mg}\left(\mathrm{B}_{3} \mathrm{H}_{8}\right)_{2}$ and its etherates. Inorg. Chem. 2007, 46, 9060-9066. [CrossRef]

39. Pistidda, C.; Garroni, S.; Dolci, F.; Gil Bardají, E.; Khandelwal, A.; Nolis, P.; Dornheim, M.; Gosalawit, R.; Jensen, T.; Cere-nius, Y.; et al. Synthesis of amorphous $\mathrm{Mg}\left(\mathrm{BH}_{4}\right)_{2}$ from $\mathrm{MgB}_{2}$ and $\mathrm{H}_{2}$ at room temperature. J. Alloys Comp. 2010, 508, 212-215. [CrossRef]

40. Severa, G.; Rönnebro, E.; Jensen, C.M. Direct hydrogenation of magnesium boride to magnesium borohydride: Demonstration of $>11$ weight percent reversible hydrogen storage. Chem. Commun. 2010, 46, 421-423. [CrossRef]

41. Sugai, C.; Kim, S.; Severa, G.; White, J.L.; Leick, N.; Martinez, M.B.; Gennett, T.; Stavila, V.; Jensen, C. Kinetic Enhancement of Direct Hydrogenation of $\mathrm{MgB}_{2}$ to $\mathrm{Mg}\left(\mathrm{BH}_{4}\right)_{2}$ upon Mechanical Milling with THF, $\mathrm{MgH}_{2}$, and/or Mg. ChemPhysChem 2019, 20, 1301-1304. [CrossRef]

42. Pistidda, C.; Santhosh, A.; Jerabek, P.; Shang, Y.; Girella, A.; Milanese, C.; Dore, M.; Garroni, S.; Bordignon, S.; Chierotti, M.R.; et al. Hydrogenation via a low energy mechanochemical approach: The $\mathrm{MgB}_{2}$ case. J. Phys. Energy 2021, 3, 044001. [CrossRef]

43. Ray, K.G.; Klebanoff, L.E.; Lee, J.R.I.; Stavila, V.; Wook Heo, T.; Shea, P.; Baker, A.A.; Kang, S.; Bagge-Hansen, M.; Liu, Y.-S.; et al. Elucidating the mechanism of $\mathrm{MgB}_{2}$ initial hydrogenation via a combined experimental-theoretical study. Phys. Chem. Chem. Phys. 2017, 19, 22646-22658. [CrossRef] [PubMed]

44. Chong, M.; Matsuo, M.; Orimo, S.; Autrey, T.; Jensen, C.M. Selective Reversible Hydrogenation of $\mathrm{Mg}\left(\mathrm{B}_{3} \mathrm{H}_{8}\right)_{2} / \mathrm{MgH}_{2}$ to $\mathrm{Mg}\left(\mathrm{BH}_{4}\right)_{2}$ : Pathway to Reversible Borane-Based Hydrogen Storage? Inorg. Chem. 2015, 54, 4120-4125. [CrossRef]

45. Yue, Y.; Chen, L.; Peng, J. Thermal Behaviors and Their Correlations of $\mathrm{Mg}\left(\mathrm{BH}_{4}\right)_{2}$-Contained Explosives. J. Energetic Mater. 2018, 36, 82-92. [CrossRef]

46. Hagemann, H. Estimation of Thermodynamic Properties of Metal Hydroborates. ChemistrySelect 2019, 4, 8989-8992. [CrossRef]

47. Chase, M.W. NIST-JANAF Thermochemical Tables. J. Phys. Chem. Ref. Data Monogr. 1998, 2. [CrossRef]

48. Hagemann, H.; D'Anna, V.; Rapin, J.-P.; Yvon, K. Deuterium-Hydrogen Exchange in Solid $\mathrm{Mg}\left(\mathrm{BH}_{4}\right)_{2}$. J. Phys. Chem. C 2010, 114, 10045-10047. [CrossRef]

49. Sharma, M.; Sethio, D.; D’Anna, V.; Fallas, J.C.; Schouwink, P.; Cerný, R.; Hagemann, H. Isotope Exchange Reactions in Ca(BH $)_{2}$. J. Phys. Chem. C 2015, 119, 29-32. [CrossRef]

50. Huang, Z.; Wang, Y.; Wang, D.; Yang, F.; Wu, Z.; Wua, L.; Zhang, Z. Role of native defects and the effects of metal additives on the kinetics of magnesium borohydride. Phys. Chem. Chem. Phys. 2019, 21, 11226-11233. [CrossRef]

51. Heere, M.; Zavorotynska, O.; Deledda, S.; Sørby, M.H.; Book, D.; Steriotis, T.; Hauback, B.C. Effect of additives, ball milling and isotopic exchange in porous magnesium borohydride. RSC Adv. 2018, 8, 27645-27653. [CrossRef]

52. Li, H.W.; Kikuchi, K.; Nakamori, Y.; Miwa, K.; Towata, S.; Orimo, S. Effects of ball milling and additives on dehydriding behaviors of well-crystallized $\mathrm{Mg}\left(\mathrm{BH}_{4}\right)_{2}$. Scr. Mater. 2007, 57, 679-682. [CrossRef]

53. Saldan, I.; Frommen, C.; Llamas-Jansa, I.; Kalantzopoulos, G.N.; Hino, S.; Arstad, B.; Heyn, R.H.; Zavorotynska, O.; Deledda, S.; Sørby, M.H.; et al. Hydrogen storage properties of gamma-Mg( $\left.\mathrm{BH}_{4}\right)_{2}$ modified by $\mathrm{MoO}_{3}$ and $\mathrm{TiO}_{2}$. Int. J. Hydrog. Energy 2015, 40, 12286-12293. [CrossRef]

54. Chong, M.; Autrey, T.; Jensen, C.M. Lewis Base Complexes of Magnesium Borohydride: Enhanced Kinetics and Product Selectivity upon Hydrogen Release. Inorganics 2017, 5, 89. [CrossRef] 
55. Dimitrievska, M.; Chong, M.; Bowden, M.E.; Wu, H.; Zhou, W.; Nayyar, I.; Ginovska, B.; Gennett, T.; Autrey, T.; Jensen, C.M.; et al. Structural and reorientational dynamics of tetrahydroborate $\left(\mathrm{BH}_{4}{ }^{-}\right)$and tetrahydrofuran (THF) in a $\mathrm{Mg}\left(\mathrm{BH}_{4}\right)_{2} \cdot 3 \mathrm{THF}$ adduct: Neutron-scattering characterization. Phys. Chem. Chem. Phys. 2020, 22, 368-378. [CrossRef]

56. Tran, B.L.; Allen, T.N.; Bowden, M.E.; Autrey, T.; Jensen, C.M. Effects of Glymes on the Distribution of $\mathrm{Mg}\left(\mathrm{B}_{10} \mathrm{H}_{10}\right)$ and $\mathrm{Mg}\left(\mathrm{B}_{12} \mathrm{H}_{12}\right)$ from the Thermolysis of $\mathrm{Mg}\left(\mathrm{BH}_{4}\right)_{2}$. Inorganics 2021, 9, 41. [CrossRef]

57. Bell, R.T.; Strange, N.A.; Leick, N.; Stavila, V.; Bowden, M.E.; Autrey, T.S.; Gennett, T. $\mathrm{Mg}\left(\mathrm{BH}_{4}\right)_{2}$-Based Hybrid Metal-Organic Borohydride System Exhibiting Enhanced Chemical Stability in Melt. ACS Appl. Energy Mater. 2021, 4, 1704-1713. [CrossRef]

58. Wegner, W.; Jaroń, T.; Dobrowolski, M.A.; Dobrzycki, Ł.; Cyrańskic, M.K.; Grochala, W. Organic derivatives of Mg(BH4)2 as precursors towards MgB2 and novel inorganic mixed-cation borohydrides. Dalton Trans. 2016, 45, 14370-14377. [CrossRef]

59. Moury, R.; Gigante, A.; Remhof, A.; Roedern, E.; Hagemann, H. Experimental investigation of $\mathrm{Mg}\left(\mathrm{B}_{3} \mathrm{H}_{8}\right)_{2}$ dimensionality, materials for energy storage applications. Dalton Trans. 2020, 49, 12168-12173. [CrossRef]

60. Gigante, A.; Leick, N.; Lipton, A.S.; Tran, B.; Strange, N.A.; Bowden, M.; Martinez, M.B.; Moury, R.; Gennett, T.; Hagemann, H.; et al. Thermal Conversion of Unsolvated $\mathrm{Mg}\left(\mathrm{B}_{3} \mathrm{H}_{8}\right)_{2}$ to $\mathrm{BH}_{4}{ }^{-}$in the Presence of $\mathrm{MgH}_{2}$. ACS Appl. Energy Mater. 2021, 4 , 3737-3747. [CrossRef]

61. Newhouse, R.J.; Stavila, V.; Hwang, S.-J.; Klebanoff, L.E.; Zhang, J.Z. Reversibility and Improved Hydrogen Release of Magnesium Borohydride. J. Phys. Chem. C 2010, 114, 5224-5232. [CrossRef]

62. Beall, H.; Gaines, D.F. Mechanistic aspects of boron hydride reactions. Inorg. Chim. Acta 1999, 289, 1-10. [CrossRef]

63. Kurbonbekov, A.; Alikhanova, T.K.; Badalov, A.; Murufi, V.K.; Mirsaidov, U. Solubility in the lanthanum borohydride -potassium borohydride -tetrahydrofuran system at $25^{\circ} \mathrm{C}$ and some thermodynamic characteristics of lanthanum borohydride. Dokl. Akad. Nauk Tadzh. SSR 1990, 33, 393-395.

64. Huang, Z.; Chen, X.; Yisgedu, T.; Meyers, E.A.; Shore, S.G.; Zhao, J.-C. Ammonium Octahydrotriborate $\left(\mathrm{NH}_{4} \mathrm{~B}_{3} \mathrm{H}_{8}\right): \mathrm{New}$ Synthesis, Structure, and Hydrolytic Hydrogen Release. Inorg. Chem. 2011, 50, 3738-3742. [CrossRef]

65. Good, W.D.; Mansson, M. The Thermochemistry of Boron and Some of Its Compounds. The Enthalpies of Formation of Orthoboric Acid, Trimethylamineborane, and Diammoniumdecaborane. J. Phys. Chem. 1966, 70, 97-104. [CrossRef]

66. Hanumantha Rao, M.; Muralidharan, K. closo-Dodecaborate $\left(\mathrm{B}_{12} \mathrm{H}_{12}\right)^{2-}$ salts with nitrogen based cations and their energetic properties. Polyhedron 2016, 115, 105-110.

67. Dematteis, E.M.; Jensen, S.R.; Jensen, T.R.; Baricco, M. Heat capacity and thermodynamic properties of alkali and alkali-earth borohydrides. J. Chem. Thermodyn. 2020, 143, 106055. [CrossRef]

68. Pinatel, E.R.; Albanese, E.; Civalleri, B.; Baricco, M. Thermodynamic modelling of $\mathrm{Mg}\left(\mathrm{BH}_{4}\right)_{2}$. J. Alloys Comp. 2015, 645, S64-S68. [CrossRef]

69. Nguyen, M.T.; Matus, M.H.; Dixon, D.A. Heats of Formation of Boron Hydride Anions and Dianions and Their Ammonium Salts $\left[\mathrm{B}_{\mathrm{n}} \mathrm{H}_{\mathrm{m}}{ }^{\mathrm{y}-}\right]\left[\mathrm{NH}_{4}{ }^{+}\right]_{\mathrm{y}}$ with $\mathrm{y}=1-2$. Inorg. Chem. 2007, 46, 7561-7570. [CrossRef]

70. McKee, M.L. Estimation of Heats of Formation of Boron Hydrides from ab Initio Energies. J. Phys. Chem. 1990, 94, 435-440. [CrossRef]

71. Kelley, S.P.; McCrary, P.D.; Flores, L.; Garner, E.B.; Dixon, D.A.; Rogers, R.D. Structural and Theoretical Study of Salts of the $\left[\mathrm{B}_{9} \mathrm{H}_{14}\right]^{-}$Ion: Isolation of Multiple Isomers and Implications for Energy Storage. ChemPlusChem 2016, 81, 922-925. [CrossRef]

72. Sethio, D.; Lawson Daku, L.M.; Hagemann, H.; Kraka, E. Quantitative Assessment of B-B-B, B-H $\mathrm{b}_{\mathrm{b}}-\mathrm{B}$, and B-H $\mathrm{H}_{\mathrm{t}}$ Bonds: From $\mathrm{BH}_{3}$ to $\mathrm{B}_{12} \mathrm{H}_{12}{ }^{2-}$. ChemPhysChem 2019, 20, 1967-1977. [CrossRef]

73. Maillard, R.; Sethio, D.; Hagemann, H.; Lawson Daku, L.M. Accurate Computational Thermodynamics Using Anharmonic Density Functional Theory Calculations: The Case Study of B-H Species. ACS Omega 2019, 4, 8786-8794. [CrossRef]

74. Yu, C.L.; Bauer, S.H. Thermochemistry of the boranes. J. Phys. Chem. Ref. Data 1998, 27, 807-835. [CrossRef]

75. Lee, T.B.; Mc Kee, M.L. Redox Energetics of Hypercloso Boron Hydrides $\mathrm{B}_{n} \mathrm{H}_{n}(\mathrm{n}=6-13)$ and $\mathrm{B}_{12} \mathrm{X}_{12}(\mathrm{X}=\mathrm{F}, \mathrm{Cl}, \mathrm{OH}$, and CH$)$. Inorg. Chem. 2012, 51, 4205-4214. [CrossRef]

76. Lee, T.B.; Mc Kee, M.L. Dissolution Thermochemistry of Alkali Metal Dianion Salts $\left(\mathrm{M}_{2} \mathrm{X}_{1}, \mathrm{M}=\mathrm{Li}^{+}, \mathrm{Na}^{+}\right.$, and $\mathrm{K}^{+}$with $\mathrm{X}=\mathrm{CO}_{3}{ }^{2-}$, $\mathrm{SO}_{4}{ }^{2-}, \mathrm{C}_{8} \mathrm{H}_{8}{ }^{2-}$, and $\mathrm{B}_{12} \mathrm{H}_{12}{ }^{2-}$ ). Inorg. Chem. 2011, 50, 11412-11422. [CrossRef]

77. Yan, Y.; Remhof, A.; Rentsch, D.; Züttel, A. The role of $\mathrm{MgB}_{12} \mathrm{H}_{12}$ in the hydrogen desorption process of $\mathrm{Mg}\left(\mathrm{BH}_{4}\right)_{2}$. Chem. Commun. 2015, 51, 700-702.

78. Yan, Y.; Remhof, A.; Rentsch, D.; Lee, Y.S.; Cho, Y.W.; Züttel, A. Is $\mathrm{Y}_{2}\left(\mathrm{~B}_{12} \mathrm{H}_{12}\right)_{3}$ the main intermediate in the decomposition process of $\mathrm{Y}\left(\mathrm{BH}_{4}\right)_{3}$ ? Chem. Commun. 2013, 49, 5234-5236. [CrossRef]

79. Godfroid, R.A.; Hill, T.G.; Onak, T.P.; Shore, S.G. Formation of $\left[\mathrm{BH}_{3}\right]^{2-}$ and $\left[\mathrm{B}_{2} \mathrm{H}_{6}\right]^{2-}$ From the Homogeneous Reduction of $\mathrm{B}_{2} \mathrm{H}_{6}$. J. Am. Chem. Soc. 1994, 116, 12107-12108. [CrossRef]

80. Hill, T.G.; Godfroid, R.A.; White III, J.P.; Shore, S.G. Reduction of borane THF by alkali metal (potassium, rubidium, cesium) and ytterbium mercury amalgams to form salts of octahydrotriborate(1-); a simple procedure for the synthesis of tetraborane(10). Inorg. Chem. 1991, 30, 2952-2954. [CrossRef]

81. Gaines, D.F.; Schaeffer, R.; Tebbe, F. Convenient Preparations of Solutions Containing the Triborohydride Ion. Inorg. Chem. 1963, 2, 526-528. [CrossRef]

82. Chen, X.; Liu, X.-R.; Wang, X.; Chen, X.-M.; Jing, Y.; Wie, D. A Safe and Efficient Synthetic Method of the Alkali Metal Octahydrotriborate, Unravelling a General Mechanism of Constructing the Delta B3 Unit of Polyhedral Boranes. Dalton Trans. 2021, 50, 13676-13679. [CrossRef] 
83. Chen, X.-M.; Ma, N.; Zhang, Q.-F.; Wang, J.; Feng, X.; Wei, C.; Wang, L.-S.; Zhang, J.; Chen, X. Elucidation of the Formation Mechanisms of the Octahydrotriborate Anion $\left(\mathrm{B}_{3} \mathrm{H}_{8}{ }^{-}\right)$through the Nucleophilicity of the B-H Bond. J. Amer. Chem. Soc. 2018, 140, 6718-6726. [CrossRef]

84. Moury, R.; Gigante, A.; Hagemann, H. An alternative approach to the synthesis of $\mathrm{NaB}_{3} \mathrm{H}_{8}$ and $\mathrm{Na}_{2} \mathrm{~B}_{12} \mathrm{H}_{12}$ for solid electrolyte applications. Int. J. Hydrog. Energy 2017, 42, 22417-22421. [CrossRef]

85. Grinderslev, J.B.; Møller, K.T.; Yan, Y.; Chen, X.-M.; Li, Y.; Li, H.-W.; Zhou, W.; Skibsted, J.; Chen, X.; Jensen, T.R. Potassium octahydridotriborate: Diverse polymorphism in a potential hydrogen storage material and potassium ion conductor. Dalton Trans. 2019, 48, 8872-8881. [CrossRef]

86. Gigante, A.; Duchêne, L.; Moury, R.; Pupier, M.; Remhof, A.; Hagemann, H. Direct solution-based synthesis of the $\mathrm{Na}_{4}\left(\mathrm{~B}_{12} \mathrm{H}_{12}\right)\left(\mathrm{B}_{10} \mathrm{H}_{10}\right)$ solid electrolyte. ChemSusChem 2019, 12, 4832-4837. [CrossRef]

87. Aniya, M. A chemical approach for the microscopic mechanism of fast ion transport in solids. Solid State Ion. 1992, 50, 125-129. [CrossRef]

88. Matsuo, M.; Nakamori, Y.; Orimo, S.; Maekawa, H.; Takamura, H. Lithium superionic conduction in lithium borohydride accompanied by structural transition. Appl. Phys. Lett. 2007, 91, 224103. [CrossRef]

89. Muetterties, E.L.; Balthis, J.H.; Chia, Y.T.; Knoth, W.H.; Miller, H.C. Chemistry of Boranes. VIII. Salts and Acids of $\mathrm{B}_{10} \mathrm{H}_{10}{ }^{-2}$ and $\mathrm{B}_{12} \mathrm{H}_{12}{ }^{-2}$. Inorg. Chem. 1964, 3, 444-451. [CrossRef]

90. Černý, R.; Brighi, M.; Murgia, F. The Crystal Chemistry of Inorganic Hydroborates. Chemistry 2020, 2, 805-826. [CrossRef]

91. Wu, H.; Tang, W.S.; Stavila, V.; Zhou, W.; Rush, J.J.; Udovic, T.J. Structural Behavior of $\mathrm{Li}_{2} \mathrm{~B}_{10} \mathrm{H}_{10}$. J. Phys. Chem. C 2015, 119, 6481-6487. [CrossRef]

92. Her, J.-H.; Yousufuddin, M.; Zhou, W.; Jalisatgi, S.S.; Kulleck, J.G.; Zan, J.A.; Hwang, S.-J.; Bowman, R.C.; Udovic, T.J. Crystal structure of $\mathrm{Li}_{2} \mathrm{~B}_{12} \mathrm{H}_{12}$ : A possible intermediate species in the decomposition of $\mathrm{LiBH}_{4}$. Inorg. Chem. 2008, 47, 9757-9759. [CrossRef]

93. Paskevicius, M.; Pitt, M.P.; Brown, D.H.; Sheppard, D.A.; Chumphongphan, S.; Buckley, C.E. First-order phase transition in the $\mathrm{Li}_{2} \mathrm{~B}_{12} \mathrm{H}_{12}$ system. Phys. Chem. Chem. Phys. 2013, 15, 15825-15828. [CrossRef] [PubMed]

94. Wu, H.; Tang, W.S.; Zhou, W.; Stavila, V.; Rush, J.J.; Udovic, T.J. The structure of monoclinic $\mathrm{Na}_{2} \mathrm{~B}_{10} \mathrm{H}_{10}$ : A combined diffraction, spectroscopy, and theoretical approach. Cryst. Eng. Comm. 2015, 17, 3533-3540. [CrossRef]

95. Verdal, N.; Her, J.-H.; Stavila, V.; Soloninin, A.V.; Babanova, O.A.; Skripov, A.V.; Udovic, T.J.; Rush, J.J. Complex high-temperature phase transitions in $\mathrm{Li}_{2} \mathrm{~B}_{12} \mathrm{H}_{12}$ and $\mathrm{Na}_{2} \mathrm{~B}_{12} \mathrm{H}_{12}$. J. Solid State Chem. 2014, 212, 81-91. [CrossRef]

96. Wunderlich, J.A.; Lipscomb, W.N. Structure of $\mathrm{B}_{12} \mathrm{H}_{12}{ }^{-2}$ ion. J. Am. Chem. Soc. 1960, 82, 4427-4428. [CrossRef]

97. Hofmann, K.; Albert, B. Crystal structures of $\mathrm{M}_{2}\left[\mathrm{~B}_{10} \mathrm{H}_{10}\right](\mathrm{M}=\mathrm{Na}, \mathrm{K}, \mathrm{Rb})$ via real space simulated annealing powder techniques. Z. Kristall. 2005, 220, 142-146. [CrossRef]

98. Bukovsky, E.V.; Peryshkov, D.V.; Wu, H.; Zhou, W.; Tang, W.S.; Jones, W.M.; Stavila, V.; Udovic, T.J.; Strauss, S.H. Comparison of the Coordination of $\mathrm{B}_{12} \mathrm{~F}_{12}{ }^{2-}, \mathrm{B}_{12} \mathrm{Cl}_{12}{ }^{2-}$, and $\mathrm{B}_{12} \mathrm{H}_{12}{ }^{2-}$ to $\mathrm{Na}+$ in the Solid State: Crystal Structures and Thermal Behavior of $\mathrm{Na}_{2} \mathrm{~B}_{12} \mathrm{~F}_{12}, \mathrm{Na}_{2}\left(\mathrm{H}_{2} \mathrm{O}\right)_{4} \mathrm{~B}_{12} \mathrm{~F}_{12}, \mathrm{Na}_{2} \mathrm{~B}_{12} \mathrm{Cl}_{12}$, and $\mathrm{Na}_{2}\left(\mathrm{H}_{2} \mathrm{O}\right)_{6} \mathrm{~B}_{12} \mathrm{Cl}_{12}$. Inorg. Chem. 2017, 56, 4369-4379. [CrossRef] [PubMed]

99. Tiritiris, I.; Schleid, T. The Dodecahydro-closo-Dodecaborates $\mathrm{M}_{2}\left[\mathrm{~B}_{12} \mathrm{H}_{12}\right]$ of the Heavy Alkali Metals $\left(\mathrm{M}=\mathrm{K}^{+}, \mathrm{Rb}^{+}, \mathrm{NH}_{4}{ }^{+}, \mathrm{Cs}^{+}\right)$ and their Formal Iodide Adducts $\mathrm{M}_{3} \mathrm{I}\left[\mathrm{B}_{12} \mathrm{H}_{12}\right]$ (= MI· $\left.\mathrm{M}_{2}\left[\mathrm{~B}_{12} \mathrm{H}_{12}\right]\right)$. Z. Anorg. Allg. Chem. 2003, 629, 1390-1402. [CrossRef]

100. Guggenberger, L.J. Chemistry of boranes. XXXIII. The crystal structure of $\mathrm{Rb}_{2} \mathrm{~B}_{9} \mathrm{H}_{9}$. Inorg. Chem. 1968, 7, 2260-2264. [CrossRef]

101. Verdal, N.; Wu, H.; Udovic, T.J.; Stavila, V.; Zhou, W.; Rush, J.J. Evidence of a transition to reorientational disorder in the cubic alkali-metal dodecahydro-closo-dodecaborates. J. Solid State Chem. 2011, 184, 3110-3116. [CrossRef]

102. Moury, R.; Lodziana, Z.; Remhof, A.; Duchêne, L.; Roedern, E.; Gigante, A.; Hagemann, H. Pressure-induced phase transitions in $\mathrm{Na}_{2} \mathrm{~B}_{12} \mathrm{H}_{12}$, structural investigation on a candidate for solid-state electrolyte. Acta Cryst. B 2019, B75, 406-413. [CrossRef]

103. Maekawa, H.; Matsuo, M.; Takamura, H.; Ando, M.; Noda, Y.; Karahashi, T.; Orimo, S. Halide-stabilized LiBH 4 , a roomtemperature lithium fast-ion conductor. J. Am. Chem. Soc. 2009, 894-895. [CrossRef]

104. Gulino, V.; Brighi, M.; Dematteis, E.M.; Murgia, F.; Nervi, C.; Cerny, R.; Baricco, M. Phase Stability and Fast Ion Conductivity in the Hexagonal $\mathrm{LiBH}_{4}$-LiBr-LiCl Solid Solution. Chem. Mater. 2019, 31, 5133-5144. [CrossRef]

105. Sadikin, Y.; Schouwink, P.; Brighi, M.; Łodziana, Z.; Cerný, R. Modified anion packing of $\mathrm{Na}_{2} \mathrm{~B}_{12} \mathrm{H}_{12}$ in close to room temperature superionic conductors. Inorg. Chem. 2017, 56, 5006-5016. [CrossRef]

106. Kim, S.; Oguchi, H.; Toyama, N.; Sato, T.; Takagi, S.; Otomo, T.; Arunkumar, D.; Kuwata, N.; Kawamura, J.; Orimo, S. A complex hydride lithium superionic conductor for high-energy-density all-solid-state lithium metal batteries. Nat. Commun. 2019, 10, 1081. [CrossRef]

107. Payandeh, S.H.; Rentsch, D.; Łodziana, Z.; Asakura, R.; Bigler, L.; Černý, R.; Battaglia, C.; Remhof, A. Nido-Hydroborate-Based Electrolytes for All-Solid-State Lithium Batteries. Adv. Funct. Mater. 2021, 31, 2010046. [CrossRef]

108. Brighi, M.; Murgia, F.; Łodziana, Z.; Schouwink, P.; Wołczyk, A.; Černý, R. A mixed anion hydroborate/carba-hydroborate as a room temperature Na ion solid electrolyte. J. Power Sources 2019, 404, 7-12. [CrossRef]

109. Duchêne, L.; Kühnel, R.-S.; Rentsch, D.; Remhof, A.; Hagemann, H.; Battaglia, C. A highly stable sodium solid-state electrolyte based on a dodeca/deca-borate equimolar mixture. Chem. Commun. 2017, 53, 4195-4198. [CrossRef]

110. Yoshida, K.; Sato, T.; Unemoto, A.; Matsuo, M.; Ikeshoji, T.; Udovic, T.J.; Orimo, S.I. Fast sodium ionic conduction in $\mathrm{Na}_{2} \mathrm{~B}_{10} \mathrm{H}_{10^{-}}$ $\mathrm{Na}_{2} \mathrm{~B}_{12} \mathrm{H}_{12}$ pseudo-binary complex hydride and application to a bulk-type all-solid-state battery. Appl. Phys. Lett. 2017, 110, 103901. [CrossRef] 
111. Payandeh, S.H.; Asakura, R.; Avramidou, P.; Rentsch, D.; Łodziana, Z.; Černý, R.; Remhof, A.; Battaglia, C. Nido-Borate/Closoborate mixed-anion electrolytes for all-solid-state batteries. Chem. Mater. 2020, 32, 1101-1110. [CrossRef]

112. Brighi, M.; Murgia, F.; Cerny, R. Closo-Hydroborate Sodium Salts as an Emerging Class of Room-Temperature Solid Electrolytes. Cell Rep. Phys. Sci. 2020, 1, 100217. [CrossRef]

113. Skripov, A.V.; Soloninin, A.V.; Babanova, O.A.; Skoryunov, R.V. Anion and Cation Dynamics in Polyhydroborate Salts: NMR Studies. Molecules 2020, 25, 2940. [CrossRef]

114. Lohstroh, W.; Heere, M. Structure and Dynamics of Borohydrides Studied by Neutron Scattering Techniques: A Review. J. Phys. Soc. Jpn. 2020, 89, 1-12. [CrossRef]

115. Duchêne, L.; Lunghammer, S.; Burankova, T.; Liao, W.-C.; Embs, J.P.; Coperet, C.; Wilkening, H.M.R.; Remhof, A.; Hagemann, H.; Battaglia, C. Ionic conduction mechanism in the $\mathrm{Na}_{2}\left(\mathrm{~B}_{12} \mathrm{H}_{12}\right)_{0.5}\left(\mathrm{~B}_{10} \mathrm{H}_{10}\right)_{0.5}$ closo-borate solid-state electrolyte: Interplay of disorder and ion-ion interactions. Chem. Mater. 2019, 31, 3449-3460. [CrossRef]

116. Asakura, R.; Duchêne, L.; Kühnel, R.-S.; Remhof, A.; Hagemann, H.; Battaglia, C. Electrochemical Oxidative Stability of Hydroborate-Based Solid-State Electrolytes. ACS Appl. Energy Mater. 2019, 2, 6924-6930. [CrossRef]

117. Matsuo, M.; Orimo, S. Lithium Fast-Ionic Conduction in Complex Hydrides: Review and Prospects. Adv. Energy Mater. 2011, 1 , 161-172. [CrossRef]

118. Duchêne, L.; Kühnel, R.-S.; Stilp, E.; Reyes, E.C.; Remhof, A.; Hagemann, H.; Battaglia, C. A Stable 3 V all-solid-state sodium-ion battery based on a closo -borate electrolyte. Energy Environ. Sci. 2017, 10, 2609-2615. [CrossRef]

119. Murgia, F.; Brighi, M.; Cerny, R. Room-temperature-operating Na-ion solid state-battery with complex hydride as electrolyte. Electrochem. Comm. 2019, 106, 106534. [CrossRef]

120. Asakura, R.; Reber, D.; Duchêne, L.; Payandeh, S.; Remhof, A.; Hagemann, H.; Battaglia, C. 4 V room-temperature all-solid-state sodium battery enabled by a passivating cathode/hydroborate solid electrolyte interface. Energy Environ. Sci. 2020, 13, 5048-5058. [CrossRef] 